University of Nebraska - Lincoln

DigitalCommons@University of Nebraska - Lincoln

USGS Staff -- Published Research

US Geological Survey

2013

Some thoughts on the factors that controlled prehistoric maize production in the American Southwest with application to southwestern Colorado

Larry Benson

University of Colorado at Boulder, great.basin666@gmail.com

D. K. Ramsey

US Department of Agriculture-Natural Resources Conservation Service

David W. Stahle

University of Arkansas, dstahle@uark.edu

K.L.Peterson

University of Utah, ken.petersen@utah.edu

Follow this and additional works at: http://digitalcommons.unl.edu/usgsstaffpub

Benson, Larry; Ramsey, D. K.; Stahle, David W.; and Peterson, K. L., "Some thoughts on the factors that controlled prehistoric maize production in the American Southwest with application to southwestern Colorado" (2013). USGS Staff -- Published Research. 779. http:// digitalcommons.unl.edu/usgsstaffpub/779

This Article is brought to you for free and open access by the US Geological Survey at DigitalCommons@University of Nebraska - Lincoln. It has been accepted for inclusion in USGS Staff -- Published Research by an authorized administrator of DigitalCommons@University of Nebraska - Lincoln. 


\title{
Some thoughts on the factors that controlled prehistoric maize production in the American Southwest with application to southwestern Colorado
}

\author{
L.V. Benson ${ }^{\text {a,* }}$, D.K. Ramsey ${ }^{\text {b }}$, D.W. Stahle ${ }^{\text {c }}$, K.L. Petersen ${ }^{\text {d }}$ \\ ${ }^{a}$ Museum of Natural History, University of Colorado, 602 Pine St., Boulder, CO 80302, USA \\ ${ }^{\mathrm{b}}$ US Department of Agriculture-Natural Resources Conservation Service, 1281 County Rd 123, Hesperus, CO 813226, USA \\ ${ }^{\mathrm{c}}$ Department of Geosciences, University of Arkansas, Fayetteville, AR 72701, USA \\ ${ }^{\mathrm{d}}$ Geography Department, University of Utah, 260 Central Campus Drive, Room 270, Salt Lake City, UT 84112, USA
}

\section{A R T I C L E I N F O}

\section{Article history:}

Received 7 January 2013

Received in revised form

13 March 2013

Accepted 14 March 2013

\section{Keywords:}

Maize agriculture

Southwestern Colorado

\begin{abstract}
A B S T R A C T
In this paper, we present a model of prehistoric southwestern Colorado maize productivity. The model is based on a tree-ring reconstruction of water-year precipitation for Mesa Verde for the period A.D. 480 to 2011. Correlation of historic Mesa Verde precipitation with historic precipitation at 11 other weather stations enabled the construction of an elevation-dependent precipitation function. Prehistoric water-year precipitation values for Mesa Verde together with the elevation-dependent precipitation function allowed construction of the elevation of southwest Colorado precipitation contours for each year since A.D. 480 , including the $30-\mathrm{cm}$ contour, which represents the minimum amount of precipitation necessary for the production of maize and the $50-\mathrm{cm}$ contour, which represents the optimum amount of precipitation necessary for the production of maize. In this paper, calculations of prehistoric maize productivity and field life for any specific elevation are also demonstrated. These calculations were performed using organic nitrogen measurements made on seven southwestern Colorado soil groups together with values of reconstructed water-year precipitation and estimations of the organic nitrogen mineralization rate.
\end{abstract}

Published by Elsevier Ltd.

\section{Introduction}

\subsection{Study objectives}

In this study we introduce an alternative model of prehistoric maize productivity for southwestern Colorado that can be used to supplement existing models of maize productivity and (or) provide an alternative approach to the calculation of maize yield and field life. Simple calculations of the effects of changes in water-year precipitation and soil organic-nitrogen (org-N) concentrations are performed in order to illustrate their effects on maize yields. In particular, the elevations of the minimum $(30 \mathrm{~cm})$ and optimum $(50 \mathrm{~cm})$ water-year precipitation contours are calculated for the period A.D. 600 to 1350 . However, full-scale modeling of prehistoric maize productivity for southwestern Colorado is not attempted.

\subsection{Previous studies and approaches}

Several investigators (e.g., Burns, 1983; Petersen, 1994; Van West, 1994) have attempted to model prehistoric maize

\footnotetext{
* Corresponding author. Tel.: +1 3034495529.

E-mail address: lbenson@usgs.gov (L.V. Benson).
}

productivity for southwestern Colorado. More recently, Kohler (2012) extended and refined the approach of Van West (1994) as part of the Village Ecodynamics Project (VEP) (Kohler et al., 2012). Kohler's (2012) maize production model consists essentially of two parts: normalization of historic bean and maize yields and the application of tree-ring-based reconstructions of two climate variables - temperature and the Palmer Drought Severity Index (PDSI) - to estimate prehistoric maize yields from soils of southwestern Colorado. An outline and critique of the existing VEP maize productivity model is given in Supplementary Appendix 1.

Kohler's (2012) maize productivity model is complex and remarkably complete in its attempt to cover all processes impacting maize productivity; however, some of the model's parameterizations are somewhat problematic. We suggest that the VEP productivity model has two principal weaknesses, its application of National Resources Conservation Service (NRCS) values of available water capacity (AWC) and normal-year dry-weight productivity (NYDWP) in a number of parameterizations and its use of two remote high-elevation Bristlecone Pine ring-width series as temperature proxies for the growing season of maize. Problems with these parameterizations and applications are also discussed in Supplementary Appendix 1 . 


\section{A different approach to the modeling of maize productivity}

In this paper, we introduce a somewhat less complicated and, arguably, less parameterized approach to modeling maize productivity in southwestern Colorado. Four key factors control maize productivity: soil moisture, soil chemistry, soil texture, and solar insolation. Precipitation and its subsequent infiltration increase soil moisture. Solar insolation drives both evaporation and evapotranspiration which decrease soil moisture. Solar insolation also provides the energy for plant photosynthesis. Soil moisture and temperature control the mineralization of org- $\mathrm{N}$ to nitrate $\left(\mathrm{NO}_{3}^{-}\right)$, which is taken up by the roots of maize and incorporated in the growing plant. Soil textures in the Southwest can be broadly divided into two categories: fine sands and silts that promote precipitation infiltration and clay-rich soils that slow infiltration and that resist the adsorption of soil moisture by roots. Although there are a variety of other chemical parameters that affect soil productivity (e.g., $\mathrm{pH}, \mathrm{P}, \mathrm{Fe}$, salinity), a soil's org-N concentration is arguably the most important measure of productivity. It should be noted, however, that elevated soil salinity can completely shut down the growth of maize (Ayers, 1977).

\subsection{Estimation of prehistoric precipitation in southwestern Colorado}

To estimate prehistoric precipitation, we first correlated standardized and detrended tree-ring indices of Mesa Verde Douglas fir to historical measurements (1949-2011) of Mesa Verde precipitation to define the seasonal precipitation response of the tree-ring data. The annual ring-width chronology is significantly correlated with precipitation during most months of the water year, so the treering data were calibrated with water-year precipitation from 1949 to 2008. Precipitation data recorded prior to the calibration period were used for validation analysis of the reconstructions (the calibration and verification results are reviewed in Supplementary Appendix 2).

We used the tree-ring calibration to reconstruct Mesa Verde precipitation rates for the period A.D. 600-1300 (Fig. 1; Supplementary Table 1 ). We then created an elevation-dependent precipitation function (Fig. 2) using data from 11 other southwestern Colorado weather stations (Table 1 ) whose locations are shown in Supplementary Fig. 1. Water-year precipitation data for the period 1964 to 1986 (when water-year data for all 12 weather stations was

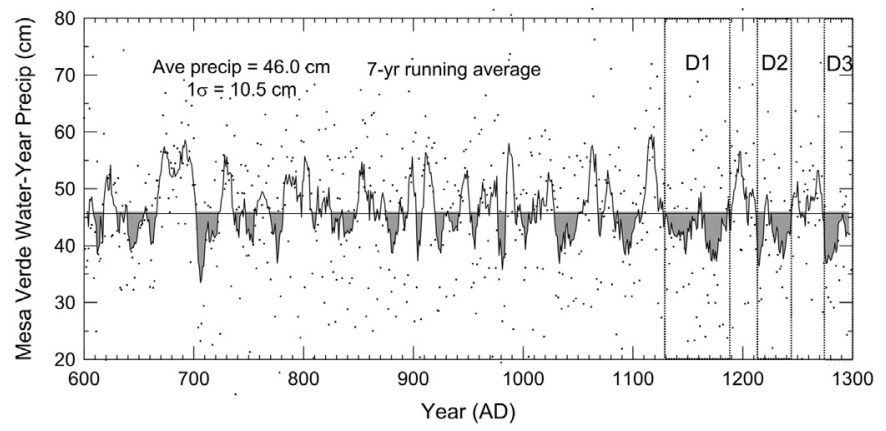

Fig. 1. Reconstructed Mesa Verde precipitation for the period A.D. 600-1300. Vertical rectangles within the 7-yr running average indicate times of relative drought. Major intense droughts are labeled D1, D2, and D3. D1 and D3 represent, respectively the middle 12th and late-13th century megadroughts that affected the Anasazi of southwestern Colorado. Megadroughts differ from other extended periods of dryness in that they lasted from 22 to 48 years and contained within them several consecutive-year dry periods, ranging from two to six years (Benson and Berry, 2009). Extended wet periods are associated with periods of intense construction activity and extended dry periods are associated with periods of little or no construction activity.

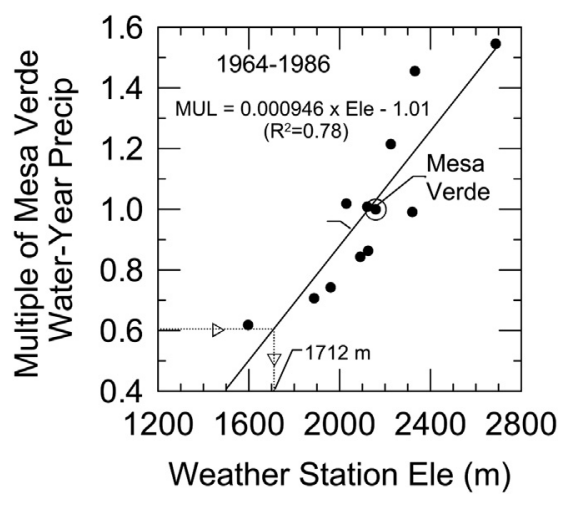

Fig. 2. Elevation dependence of water-year precipitation at 11 southwestern Colorado weather stations relative to Mesa Verde water-year precipitation. The mean value of precipitation between 1964 and 1986 for each station is plotted as a black dot.

available) were used to construct Fig. 2. Supplementary Fig. 2 shows the correlation of water-year precipitation at Mesa Verde and the other weather stations. All weather station data in this paper were taken from the Western Regional Climate Center's (2012) web page. The reconstructed prehistoric precipitation estimates can be used to calculate water-year precipitation values for any elevation in the study area during the prehistoric period, and the annual precipitation data can be used to screen for years of potential crop failure.

Inline Supplementary Table S1 can be found online at http://dx. doi.org/10.1016/j.jas.2013.03.013.

Inline Supplementary Figs. S1 and S2 can be found online at http://dx.doi.org/10.1016/j.jas.2013.03.013.

A summer rainfall of $\sim 15 \mathrm{~cm}$ and an annual precipitation of $\sim 30 \mathrm{~cm}$ represent the lower limits for dry-land (rain-on-field) maize production in the northern hemisphere (Shaw, 1988). With regard to regions near the study area, Leonard et al. (1940) observed that crop failures in Colorado usually occurred when annual rainfall was $<35 \mathrm{~cm}$, and Jenkins (1941) suggested that precipitation of $\sim 20 \mathrm{~cm}$ during June, July, and August marked the western limit of maize production in the United States. Thus, for every field site at a particular elevation at a particular time, annual values of precipitation $<30 \mathrm{~cm}$ can be used to set maize yields to zero. It should be noted that ordinary water use by maize ranges from 41 to $64 \mathrm{~cm}$ (Hanway, 1966); thus values below $40 \mathrm{~cm}$ are probably indicative of times of moisture stress in southwestern Colorado, where the warm-season bare-soil evaporation rate is extremely high.

Mesa Verde's water-year precipitation has averaged $47.8 \pm 10.6 \mathrm{~cm}$ for the period 1964-1986. Although the fit value $(49.3 \mathrm{~cm}$, Fig. 2$)$ is slightly larger than $47.8 \mathrm{~cm}$, we elected to use the fitted value when evaluating relative changes in precipitation as a function of elevation.

Table 1

Multiples of Mesa Verde precipitation and water-year statistics.

\begin{tabular}{|c|c|c|c|c|c|c|}
\hline \multicolumn{2}{|c|}{ Weather station (m) } & \multirow{2}{*}{$\frac{\text { Water yr }}{(1964-1986)}$} & \multirow{2}{*}{$\frac{\text { Annual yr }}{\text { All data }}$} & \multirow{2}{*}{$\frac{\text { Jun-Sep }}{\text { All data }}$} & \multicolumn{2}{|l|}{ Water yr $(\mathrm{cm})$} \\
\hline & & & & & $(1964-1986)$ & $1 \sigma$ \\
\hline Hovenweep & 1597 & 0.62 & 0.59 & 0.54 & 29.6 & 9.6 \\
\hline Cortez & 1888 & 0.71 & 0.69 & 0.73 & 33.8 & 9.1 \\
\hline Ignacio & 1960 & 0.74 & 0.78 & 0.87 & 35.5 & 9.0 \\
\hline Durango & 2030 & 1.02 & 1.03 & 1.09 & 48.7 & 12.2 \\
\hline Yellow Jacket & 2091 & 0.84 & 0.85 & 0.85 & 40.3 & 9.7 \\
\hline Dolores & 2121 & 1.01 & 1.01 & 0.90 & 48.2 & 13.0 \\
\hline Mancos & 2126 & 0.86 & 0.88 & 0.94 & 41.3 & 10.2 \\
\hline Mesa Verde & 2159 & 1.00 & 1.00 & 1.00 & 47.8 & 10.6 \\
\hline Tacoma & 2225 & 1.22 & 1.18 & 1.38 & 58.1 & 10.9 \\
\hline Fort Lewis & 2320 & 0.99 & 0.98 & 1.07 & 47.4 & 11.1 \\
\hline Vallecito Dam & 2332 & 1.46 & 1.46 & 1.60 & 69.6 & 17.1 \\
\hline Rico & 2687 & 1.55 & 1.45 & 1.50 & 73.9 & 14.9 \\
\hline
\end{tabular}


A 30-cm precipitation minimum represents a $(30 / 49.3)=0.61 \mathrm{mul}-$ tiple of Mesa Verde's average precipitation, which implies that maize could not have been grown below $1712 \mathrm{~m}$ during much of the historical period (Fig. 2). Actually, the data often fall outside the linear fit by $\pm 150 \mathrm{~m}$, indicating the approximate error in the calculation. Crop insurance for dry-land farming is not issued for elevations below $1830 \mathrm{~m}$ (Petersen, 1987b), which suggests that the lower elevation for historic maize production may be $\sim 120 \mathrm{~m}$ higher than the value calculated using the linear fit displayed in Fig. 2 or that the insurance companies are erring on the side of caution by taking into account exceptionally dry years that occurred in the historical record. Obviously there is a great deal of variability in precipitation at any elevation from year to year (Fig. 3); thus, the dependence of precipitation on elevation for any particular water year will not be the same as the dependence of mean values of water-year precipitation with elevation as shown by the fit line in Fig. 2. However, for the purposes of this paper, we will assume that the linear regression depicted in Fig. 2 represents a fairly robust approximation of water-year precipitation for any particular elevation relative to the amount of precipitation measured at mesa Verde and that this relation allows us to approximate the relative movement of the $30-$ and $50-\mathrm{cm}$ precipitation contours over the period A.D. 600 to 1350 .

\subsection{Grouping of soil types}

The Cortez Soil Survey area consists of 152 mappable units, covering the area from the deserts of the Four Corners at $\sim 1220 \mathrm{~m}$ to the Ponderosa Pine forest along the Dolores River Canyon at $2600 \mathrm{~m}$ (Ramsey, 1997). We aggregated the 152 soils (Supplementary Table 2) into 12 groups based on similar soil and environmental parameters. Seven of the groups were deemed suitable for maize production and five were considered unsuitable for farming (Table 2). Supplementary Fig. 1 shows the locations of the 12 grouped soils in the study area and Supplementary Fig. 3 shows the vegetation types that populate the seven productive soils.

Inline Supplementary Table S2 can be found online at http://dx. doi.org/10.1016/j.jas.2013.03.013.

Inline Supplementary Fig. S3 can be found online at http://dx. doi.org/10.1016/j.jas.2013.03.013.

\subsection{The org- $N$ content of the seven soil groups}

As mentioned in the previous section, only seven of the 12 soil groups were considered productive in terms of dry-land maize

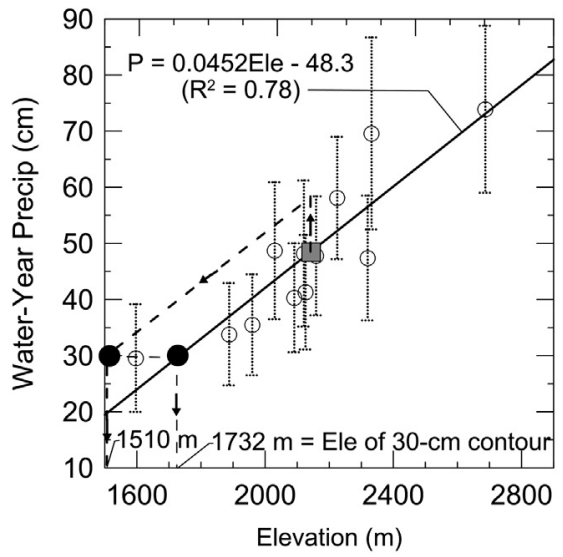

Fig. 3. Water-year precipitation as a function of elevation for 12 weather stations in southwestern Colorado. Error bars indicate $\pm 1 \sigma$ variation in precipitation a particular station. Heavy dashed line with arrows indicates the effect of increasing precipitation by $10 \mathrm{~cm}$ on the elevation of $30-\mathrm{cm}$ precipitation contour; i.e., it shifts from an elevation of 1732 to $1510 \mathrm{~m}$ (see text for further discussion).
Table 2

Grouping of southwest Colorado soils.

\section{Soils suitable for farming}

CE: Cool eolian soils. These soils are located at the higher elevations along the Dolores River canyon rim. They are formed mainly from eolian material with some input from local residual materials. Due to the natural sorting of the eolian material, and increased precipitation due to elevation, these soils tend to be higher in clay content than the soils at lower elevations that are closer to the source of the eolian material. The soils are generally deep to very deep with some area of stone content. Vegetation is mainly Gambels oak and ponderosa pine.

DE: Deep eolian soils. These soils are located across the mesa tops and uplands of the survey area. They are extensive and are the sites of current agricultural. They are moderately deep to very deep and generally free of any stones. These soils tend to have high concentrations of very fine sand and silt and have high water holding capacity. They extend from lower elevations around Hovenweep National Monument up to about $2290 \mathrm{~m}$. They lie beneath the pinion and juniper forest and the sagebrush covered mesas.

CL: Clay soils derived from the Mancos Shale. These soils are located near the town of Mancos and extend west to near the entrance to Mesa Verde National Park. These soils are deep to very deep and developed in clayey alluvium from the Mancos shale and occur on fans below shale hills. Vegetation is generally composed of big sagebrush with pinion and juniper along the edges and on adjoining clay hills.

AL: Alluvial soils. These soils are a mixture of eolian material and alluvium from sandstone and shale. These soils tend to be sandy to loamy and occur in narrow swales and along narrow streams. Most of these areas do not have perennial streams but may receive water during spring snow melt or heavy thunderstorms. The alluvial soils are scattered throughout the mesas and valleys. Vegetation is mainly big sagebrush with areas of greasewood and four wing saltbush.

FN: Soils on alluvial fans. These soils are located along the toe slope of Mesa Verde near the entrance of the park and extending around the mesa past Towaoc. These soils are very deep, stratified, and loamy textured. They have uniform slopes and few stones larger than gravel. Vegetation consists mainly of big sage.

MVL: Eolian soils of Mesa Verde. These soils are moderately deep and to very deep eolian soils on the top of Mesa Verde. Because of the increased precipitation and longer growing season at these elevations, these soils were identified to have greater agricultural potential than other similar soils in the region. These soils have high water holding capacity and silt loam to clay loam textures.

CAL: Alluvial soils of Mesa Verde. These soils are located in the upper reaches of the major valleys that transect Mesa Verde. They are deep to very deep, well developed soils that have higher levels of organic material than most other alluvial soils. They are sites of increased precipitation and, in some settings, contain seasonal water tables.

Soils unsuitable for farming

ST: Steep soils of various parent materials

DR: Desert soils not suitable for farming

MC: Miscellaneous areas, dams, rock outcrop, water

SH: Shallow soils to bedrock

ED: Dry eolian soils of the desert.

farming. Our procedure considers org- $\mathrm{N}$ and its mineralization rate as two of four principal arbiters of maize productivity. To implement this concept, in September of 2011, we collected the upper $50 \mathrm{~cm}$ of a set $(n \sim 30)$ of soil samples from each of the 7 soil groups. Soil samples referenced in this paper also were taken from Mesa Verde, Bandelier, and other areas in and around the San Juan Basin. The latter soil samples were collected from two depth ranges, 1026 and 40-46 cm (Benson, 2010a). Locations of samples were obtained using a handheld GPS, usually accurate to $<5 \mathrm{~m}$. Samples were oven dried and the dried sample was disaggregated using a mortar and pestle. The disaggregated soil was then passed through a $2-\mathrm{mm}$ screen and all particles $>2 \mathrm{~mm}$ were discarded. The screened sample was homogenized by passing the sample five times through a riffle-type sample splitter. Total carbon (TC) (data not reported) and total nitrogen (TN) were determined on $\sim 2 \mathrm{mg}$ of ground sample, using an Exeter Analytical Model CE-440 rapid analysis elemental analyzer. The TN value should be considered 
equivalent to the total org- $\mathrm{N}$ value of a soil. The org-N data resulting from this study is listed in Supplementary Table 3 and summarized in Table 3.

Inline Supplementary Table S3 can be found online at http://dx. doi.org/10.1016/j.jas.2013.03.013.

\subsection{Org- $N$ and maize yields}

As discussed in Benson (2010b), the modern above-ground maize plant contains $3.3 \mathrm{~g} \mathrm{~N}$, and its root mass contains $0.4 \mathrm{~g} \mathrm{~N}$; therefore, hills containing 2, 4, and 5 stalks of maize need, respectively, 7.4,14.8, and $18.5 \mathrm{~g}$ of $\mathrm{N}$ in the form of $\mathrm{NO}_{3}^{-}$. The $\mathrm{NO}_{3}^{-}$is produced by the mineralization of org- $\mathrm{N}$ within the soil. The $\mathrm{NO}_{3}^{-}$is highly mobile and is rapidly lost from the soil whether the plant absorbs it or not. Thus, once a field is cleared for planting, org-N will continually mineralize to $\mathrm{NO}_{3}^{-}$and will be irreversibly lost from the soil zone. Elevated temperatures increase the activity of the microbial community in relatively wet regions, increasing the mineralization rate of org- $\mathrm{N}$; however, in semiarid climates, increasing temperature dries the soil and reduces the decomposition rate of org-N. Greater soil moisture also translates into enhanced rates of microbial activity (Hoeft and Peck, 2002; Williams et al., 2000) and, therefore, increased mineralization rates. Thus the mineralization of org- $\mathrm{N}$ is both a function of temperature and precipitation.

A substantial amount of the org-N within the soil zone is not amenable to rapid mineralization. For example, Soudi et al. (1990) measured relative organic- $\mathrm{N}$ mineralization rates of eight semiarid Moroccan soils as a function of depth. The data indicate an exponential decrease in organic-N mineralization rate with depth and demonstrate that most of the org-N mineralization occurred within the upper $20-30 \mathrm{~cm}$ of the soil profile in semi-arid regions.

Data on the non-hydrolyzable component of Southwestern U.S. soils is lacking; however, data for other regions in North America suggest that approximately $50 \%$ of the upper $30-50 \mathrm{~cm}$ of North America soils is recalcitrant to mineralization (Table 5 in Benson, 2010b). Given the low amounts of mineralizable org-N below $50 \mathrm{~cm}$ (see Fig. 7 in Benson, 2010b) we make the assumption that only 50\% of the total org- $\mathrm{N}$ in the upper $50 \mathrm{~cm}$ of Southwestern fields is susceptible to mineralization.

Maize root-length density, mass, and volume decrease exponentially with depth (Dwyer et al., 1996; Fehrenbacher and Rust, 1956; Qin et al., 2006). The root volume expands and deepens with time; i.e., root-length density contours descend relatively slowly over a 16-week growing period, with the roots reaching a depth of $\sim 1 \mathrm{~m}$. The upper near-surface root-ball radii of some types of modern hybrid maize extend $1.2 \mathrm{~m}$ outward from the stalk (Weaver, 1926). If most of the roots of maize are confined to the upper half meter of the root cone, we can approximate the overall volume of the root mass by a frustum with radii of 0.6 and $1.2 \mathrm{~m}$, a height of $0.5 \mathrm{~m}$, and a volume of $1.32 \mathrm{~m}^{3}$. It is within this volume that $\mathrm{NO}_{3}^{-}$becomes available to the maize plant and at a $100 \%$ efficiency of $\mathrm{NO}_{3}^{-}$adsorption, 7.4, 14.8, and $18.5 \mathrm{~g}$ of $\mathrm{NO}_{3}^{-}$must be produced to create hills containing, respectively, 2,4 , and 5 stalks of maize.

\subsection{Organic- $N$ mineralization rates}

Soil organic matter (SOM) mineralization rates, usually refer to measurements of change in the organic carbon (org-C) component of the soil; however, as Herrmann (2003) has pointed out "Gross nitrogen mineralization is proportional to $C$ mineralization in soils, so that $\mathrm{C}$ mineralization may be used as a predictor for gross $\mathrm{N}$ mineralization."

The following equation can be used to calculate $k$ (the org-N or C mineralization rate constant) where $t$ is the time (yr) elapsed between measurements of soil org-C; i.e., the time between measurement of $\mathrm{C}_{\mathrm{o}}$ and $\mathrm{C}$.

$\ln \left[\frac{\mathrm{C}}{\mathrm{C}_{\mathrm{o}}}\right] / t=k$

Field studies in which the loss of org-N or $\mathrm{C}$ was measured over time from soils at a variety of sites indicate a range in $k$ of $0.6-2.2 \%$ / $\mathrm{yr}$ (Table 4). Unfortunately, these sites are not representative of the study area in that the climates of the experimental sites are generally wetter and usually warmer than semi-arid southwestern Colorado. Thus, the calculated $k$ values usually exceed the longterm $k$ values for SOM and org-N in the Colorado study area.

\subsection{The effect of solar radiation on maize yields}

\subsubsection{Growing degree and freeze-free days}

The most common proxy for solar radiation in agriculture is growing degree days (GDD), defined as

$$
\text { GDD }=\left[\left(T_{\text {high }}+T_{\text {low }}\right) / 2\right]-10
$$

in which $T_{\text {low }}$ and $T_{\text {high }}$ are the daily high and low temperatures $\left({ }^{\circ} \mathrm{C}\right)$, and $T_{\text {high }}$ is capped at $30^{\circ} \mathrm{C}$. Generally high (1330-1780) GDD are necessary for optimal crop yields in the Midwest where high humidity suppresses transpiration and soil evaporation; however, high GDD can negatively affect maize yields in the Southwest. For example, Petersen (1987a) found that, between 1920 and 1960, yields of dry-land maize grown in Dolores and Montezuma Counties, Colorado, were negatively related to GDD values measured at the Yellow Jacket weather station. Whereas increases in solar radiation may promote photosynthetic activity, solar radiation also increases transpiration and evaporation of soil moisture, which causes the plant to wilt. In addition, if air temperature exceeds $32{ }^{\circ} \mathrm{C}$, maize begins to stress during pollination and grainfill (Thomison et al., 2012) and temperatures in excess of $38^{\circ} \mathrm{C}$ may actually kill maize pollen (Nielson, 2012). Both processes resulted in massive crop failures in the American Midwest during the summer of 2012. Petersen (1987a) demonstrated that maize could be grown under warm ( 1400 GDD) conditions, if annual precipitation was elevated $(46 \mathrm{~cm})$, and that maize could be grown under relatively dry conditions (as little as $33 \mathrm{~cm}$ of precipitation) if the climate was cool ( 900 GDD). Bellorado (2007) demonstrated excellent yields of Hopi Blue maize in 2004 when GDD ranged between 970 and 1100 GDD at elevations ranging from 2070 to $2105 \mathrm{~m}$ in the Ridges

Table 3

Quartile and mean total $N$ values of study area soils.

\begin{tabular}{|c|c|c|c|c|c|c|c|c|c|c|c|c|}
\hline & $\begin{array}{l}\text { Morefield } \\
\text { valley } \\
\text { Alluvium }\end{array}$ & $\begin{array}{l}\text { Mesa } \\
\text { Verde } \\
\text { Alluvial fan }\end{array}$ & $\begin{array}{l}\text { SW CO } \\
\text { cool } \\
\text { Eolian }\end{array}$ & $\begin{array}{l}\text { SW CO } \\
\text { Clay }\end{array}$ & $\begin{array}{l}\text { Zuni } \\
\text { field } \\
\text { Soils }\end{array}$ & $\begin{array}{l}\text { SW CO } \\
\text { Alluvial }\end{array}$ & $\begin{array}{l}\text { Chapin } \\
\text { mesa } \\
\text { Loess }\end{array}$ & $\begin{array}{l}\text { Bandelier } \\
\text { Soils }\end{array}$ & $\begin{array}{l}\text { SW CO } \\
\text { deep } \\
\text { Eolian Loess }\end{array}$ & $\begin{array}{l}\text { Wetherill } \\
\text { mesa } \\
\text { Loess }\end{array}$ & $\begin{array}{l}\text { Chaco } \\
\text { corridor } \\
\text { Soils }\end{array}$ & $\begin{array}{l}\text { Hopi } \\
\text { dune } \\
\text { Field }\end{array}$ \\
\hline 1st quartile & 0.101 & 0.095 & 0.090 & 0.075 & 0.058 & 0.052 & 0.056 & 0.034 & 0.037 & 0.037 & 0.028 & 0.006 \\
\hline 2nd quartile & 0.116 & 0.107 & 0.098 & 0.080 & 0.073 & 0.071 & 0.070 & 0.057 & 0.053 & 0.046 & 0.044 & 0.013 \\
\hline 3rd quartile & 0.169 & 0.116 & 0.110 & 0.099 & 0.093 & 0.093 & 0.083 & 0.061 & 0.069 & 0.054 & 0.070 & 0.036 \\
\hline Mean & 0.141 & 0.109 & 0.099 & 0.085 & 0.077 & 0.074 & 0.079 & 0.050 & 0.054 & 0.048 & 0.050 & 0.020 \\
\hline
\end{tabular}


Table 4

Field-based soil organic matter mineralization rates.

\begin{tabular}{lllll}
\hline Area & Years & Plants & $N_{\text {org Min. Rate }}$ & Reference \\
\hline $\begin{array}{l}\text { Rothamsted, } \\
\quad \text { England }\end{array}$ & 100 & None & $0.59 \% / \mathrm{yr}$ & $\begin{array}{l}\text { Jenkinson and } \\
\text { Rayner (1977) }\end{array}$ \\
Nebraska & 22 & No-till wheat & $0.60 \% / \mathrm{yr}$ & Doran et al. (1998) \\
Minnesota & 9 & None & $0.69 \% / \mathrm{yr}$ & Clay et al. (2007) \\
Nebraska & 22 & No-till wheat & $0.78 \% / \mathrm{yr}$ & Doran et al. (1998) \\
Minnesota & 13 & None & $1.18 \% / \mathrm{yr}$ & Clay et al. (2007) \\
South Dakota & 5 & None & $2.21 \% / \mathrm{yr}$ & Clay et al. (2007) \\
\hline
\end{tabular}

Basin area southwest of Durango, Colorado. When GDD fell below a value of 910, maize yields declined precipitously.

Another measure of solar radiation is the length of the freezefree growing season. Most varieties of maize, including Southwest Native American landraces such as Hopi blue maize and a variety of Zuni cultivars, require about 120 freeze-free days (FFD) (e.g., Bradfield, 1971; Muenchrath et al., 2002). The 120 days refers to the time from emergence to black-layer formation which indicates physiological maturity of the maize plant. In the case of the of Hopi Blue maize grown by Bellorado (2007), good yields occurred when the length of the freeze-free period exceeded 117 days. When FFD fell to $\leq 115$ days, yields markedly decreased. Supplementary Table 4 which lists the $90 \%$ probability of FFD between $0{ }^{\circ} \mathrm{C}$ in spring and autumn as well as the probability of a site reaching 120 FFD during summer, indicates that there is a very complicated relationship between FDD and elevation in southwest Colorado. Note that the probability of achieving > 115 FFD is high for Cortez (94\%), Mesa Verde (92\%), and Yellow Jacket (88\%), but is very low for Rico (0\%), Vallecito (21\%), Ignacio (22\%) and Durango (36\%). This suggests that the latter four sites represent elevations and/or topographies inimical to maize farming during relatively warm times.

Inline Supplementary Table S4 can be found online at http://dx. doi.org/10.1016/j.jas.2013.03.013.

Optimally, we would like to include the effects of both GDD and FFD in our model of maize productivity. Unfortunately, there is also no simple relationship between GDD and elevation for the eight southwestern Colorado weather stations that record GDD (Fig. 4B),
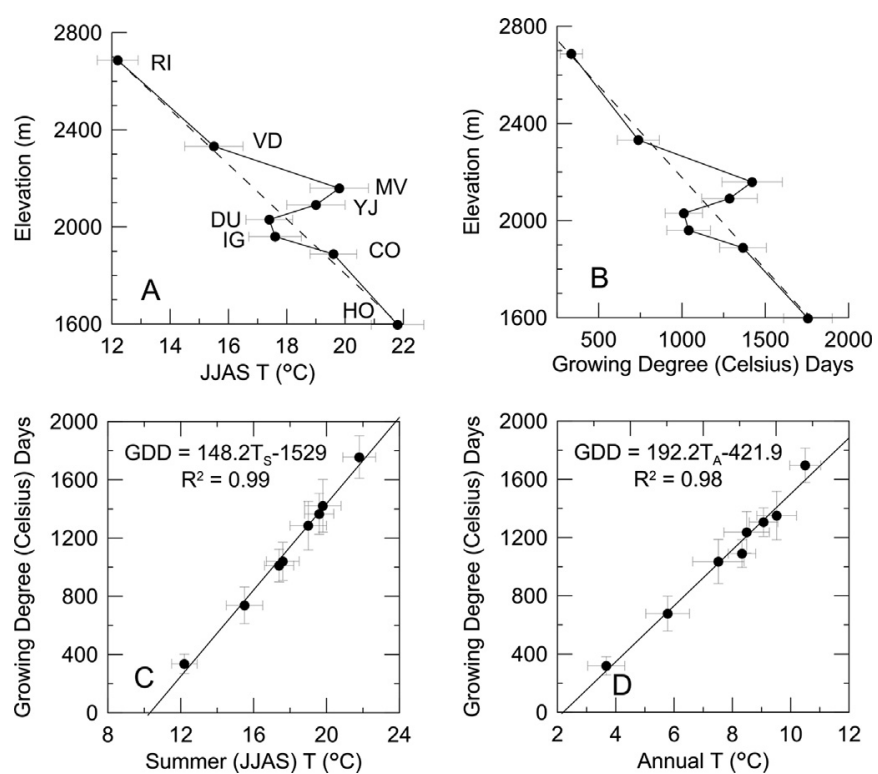

Fig. 4. A. Summer (JJAS) mean temperatures and B. growing degree days (GDD) at Rico (RI), Vallecito Dam (VD), Mesa Verde (MV), Yellow Jacket (YJ), Durango (DU), Ignacio (IG), Cortez (CO), and Hovenweep (HO) weather stations plotted as a function of elevation. GDD plotted as a function of C. summer and D. annual mean temperatures. although there is an excellent relationship between both and summer (JJAS) and mean-annual temperatures and GDD (Fig. 4C, D; see Supplementary Table 4 for temperature and GDD statistics). Even if there were a simple relationship between elevation and historic GDD, we still need to reconstruct prehistoric values of GDD, which implies we need to find a proxy for southwest Colorado prehistoric temperatures.

\subsubsection{Bristlecone Pine ring width as a proxy for prehistoric summer temperatures}

Kohler (2012) indicated some success linking prior- and currentyear September temperatures at Mesa Verde and Yellow Jacket weather stations with Bristlecone Pine ring widths at Almagre. He also was able to correlate the 1st principal component of the combined Almagre and San Francisco Peaks ring-width series to September temperatures at these two sites.

We reassessed the ability of Bristlecone Pine ring widths to reconstruct prehistoric temperatures by regressing June, July, August, and September temperatures, mean summer (JJAS) temperatures, and GDD values for each of eight weather stations against both current and prior-year ring widths of Bristlecone Pines from Almagre, Colorado (updated data set provided by Connie Woodhouse) and San Francisco Peaks, Arizona (data provided by Matthew Salzer; see also Salzer and Kipfmueller, 2005). With regard to the Almagre record, data from all eight weather stations were regressed against prewhitened standardized and detrended ring widths of Almagre Bristlecone Pine. Data from Mesa Verde and Yellow Jacket weather stations were also regressed against standardized and detrended ring widths of Almagre Bristlecone Pine that had not been prewhitened in order to determine if prewhitening negatively affected the correlations.

Of the 266 regressions, only 7 explained at least $20 \%$ of the variance of the independent thermal variable (Table 5), with most of those regressions associated with the Yellow Jacket weather station. Obviously, the locations of some of the weather stations (e.g., Rico, Vallecito Dam, Ignacio, and Durango) are outside the VEP study area; however, these sites provide data useful in determining whether growing season proxies at these elevations can be linked to high-elevation Bristlecone ring widths.

Many of the temperature and GDD correlations were negatively related to ring width, with decreasing temperatures associated with increasing ring widths (see; e.g., Fig. 5). San Francisco Peaks Bristlecone Pine ring widths failed to explain more than a few tenths of a percent of the variances in summer temperatures and GDD measured at the nearby Fort Valley weather station (Table 5), illustrating the inherent inability of the San Francisco Peaks treering record to predict growing season temperature variability. Correlations of FFD with the tree-ring records did not fare any better (Table 5). The results of these regressions suggest that, at this time, there does not exist any objective way of using high-elevation tree rings to reconstruct high-frequency (annual) prehistoric proxy records of the summer growing season in southwestern Colorado.

Instead of using tree-ring widths, it may be possible to use treering densities of high-elevation Bristlecone Pine to estimate prehistoric changes in southwest Colorado temperatures. For example, Briffa et al. (2001) have used this method to reconstruct a composite proxy-temperature series of Northern Hemisphere temperatures for the past 600 years.

\subsubsection{Pollen-based reconstructions of low-frequency temperature and precipitation variability}

Petersen (1988) used pollen ratios from two sites Beef Pasture $(3060 \mathrm{~m})$ and Twin Lakes $(3290 \mathrm{~m})$ in the LaPlata Mountains $\sim 25 \mathrm{~km}$ northwest of Durango, Colorado, to reconstruct relative changes in summer air temperature and winter precipitation for 
Table 5

$R^{2}$ of temperature proxies versus Bristlecone pine ring widths.

\begin{tabular}{|c|c|c|c|c|c|c|c|}
\hline $\begin{array}{l}\text { Weather } \\
\text { station }\end{array}$ & Jun $T$ & Jul $T$ & Aug $T$ & Sep $T$ & $\begin{array}{l}\text { Ave } \\
\text { JJAS T }\end{array}$ & GDD & FFD \\
\hline \multicolumn{8}{|c|}{$\begin{array}{l}\text { Current-year T (celsius) proxy vs prewhitened Almagre standarized } \\
\quad \text { ring widths }\end{array}$} \\
\hline Mesa Verde & 0.000 & 0.000 & 0.000 & 0.009 & 0.001 & 0.002 & 0.003 \\
\hline Hovenweep & 0.013 & 0.015 & 0.010 & 0.002 & 0.007 & 0.001 & 0.024 \\
\hline Cortez & 0.000 & 0.009 & 0.003 & 0.005 & 0.000 & 0.005 & 0.001 \\
\hline Ignacio & 0.005 & 0.002 & 0.034 & 0.019 & 0.027 & 0.018 & 0.028 \\
\hline Durango & 0.004 & 0.014 & 0.015 & 0.004 & 0.003 & 0.001 & 0.015 \\
\hline Yellow Jacket & 0.000 & 0.129 & 0.038 & 0.007 & 0.000 & 0.000 & 0.015 \\
\hline Vallecito Dam & 0.003 & 0.002 & 0.023 & 0.002 & 0.001 & 0.000 & 0.019 \\
\hline Rico & 0.001 & 0.011 & 0.026 & 0.002 & 0.000 & 0.002 & 0.000 \\
\hline \multicolumn{8}{|c|}{$\begin{array}{l}\text { Current-year T (celsius) proxy vs San Francisco Peaks standarized } \\
\quad \text { ring widths }\end{array}$} \\
\hline Mesa Verde & 0.106 & 0.025 & 0.014 & 0.007 & 0.026 & 0.051 & 0.038 \\
\hline Hovenweep & 0.000 & 0.026 & 0.006 & 0.040 & 0.000 & 0.000 & 0.000 \\
\hline Cortez & 0.000 & 0.013 & 0.022 & 0.020 & 0.011 & 0.023 & 0.040 \\
\hline Ignacio & 0.004 & 0.000 & 0.035 & 0.006 & 0.006 & 0.003 & 0.061 \\
\hline Durango & 0.082 & 0.050 & 0.200 & 0.052 & 0.148 & 0.134 & 0.007 \\
\hline Yellow Jacket & 0.018 & 0.001 & 0.187 & 0.152 & 0.119 & 0.114 & 0.035 \\
\hline Vallecito Dam & 0.000 & 0.075 & 0.006 & 0.002 & 0.007 & 0.014 & 0.018 \\
\hline Rico & 0.013 & 0.000 & 0.019 & 0.026 & 0.025 & 0.023 & 0.008 \\
\hline Fort Valley & 0.013 & 0.001 & 0.033 & 0.031 & 0.004 & 0.001 & n.d. \\
\hline \multicolumn{8}{|c|}{ Prior-year T (celsius) proxy vs prewhitened Almagre standarized ring widths } \\
\hline Mesa Verde & 0.002 & 0.010 & 0.041 & 0.031 & 0.022 & 0.000 & 0.008 \\
\hline Hovenweep & 0.003 & 0.024 & 0.085 & 0.134 & 0.102 & 0.150 & 0.032 \\
\hline Cortez & 0.001 & 0.077 & 0.097 & & 0.090 & 0.055 & 0.051 \\
\hline Ignacio & 0.000 & 0.030 & 0.009 & 0.045 & 0.027 & 0.025 & 0.014 \\
\hline Durango & 0.000 & 0.069 & 0.084 & 0.056 & 0.039 & 0.032 & 0.019 \\
\hline Yellow Jacket & 0.020 & 0.173 & 0.129 & 0.083 & 0.172 & 0.220 & 0.000 \\
\hline Vallecito Dam & 0.008 & 0.064 & 0.030 & 0.033 & 0.025 & 0.023 & 0.002 \\
\hline Rico & 0.003 & 0.075 & 0.041 & 0.087 & 0.088 & 0.114 & 0.004 \\
\hline \multicolumn{8}{|c|}{ Prior-year T (celsius) proxy vs San Francisco Peaks standarized ring widths } \\
\hline Mesa Verde & 0.044 & 0.034 & 0.028 & 0.011 & 0.018 & 0.027 & 0.014 \\
\hline Hovenweep & 0.003 & 0.046 & 0.086 & 0.008 & 0.026 & 0.022 & 0.031 \\
\hline Cortez & 0.013 & 0.027 & 0.007 & 0.011 & 0.006 & 0.010 & 0.072 \\
\hline Ignacio & 0.027 & 0.000 & 0.011 & 0.014 & 0.009 & 0.006 & 0.051 \\
\hline Durango & 0.177 & 0.074 & 0.086 & 0.066 & 0.194 & 0.155 & 0.000 \\
\hline Yellow Jacket & 0.061 & 0.004 & 0.060 & 0.176 & 0.136 & 0.095 & 0.018 \\
\hline Vallecito Dam & 0.009 & 0.057 & 0.026 & 0.000 & 0.005 & 0.009 & 0.089 \\
\hline Rico & 0.023 & 0.054 & 0.034 & 0.010 & 0.002 & 0.001 & 0.004 \\
\hline Fort Valley & 0.000 & 0.007 & 0.004 & 0.035 & 0.006 & 0.004 & n.d. \\
\hline \multicolumn{8}{|c|}{$\begin{array}{l}\text { Current-year } T \text { (celsius) proxy vs Almagre standarized ring widths not } \\
\quad \text { prewhitened }\end{array}$} \\
\hline Mesa Verde & 0.002 & 0.078 & 0.079 & 0.109 & 0.104 & 0.074 & 0.012 \\
\hline Yellow Jacket & 0.044 & 0.057 & 0.000 & 0.001 & 0.023 & 0.019 & 0.041 \\
\hline \multicolumn{8}{|c|}{$\begin{array}{l}\text { Prior-year T (celsius) proxy vs Almagre standarized ring widths not } \\
\quad \text { prewhitened }\end{array}$} \\
\hline Mesa Verde & 0.005 & 0.016 & 0.005 & 0.011 & 0.012 & 0.066 & 0.000 \\
\hline Yellow Jacket & 0.133 & 0.279 & 0.251 & 0.084 & 0.353 & 0.344 & 0.024 \\
\hline
\end{tabular}

Bold numbers indicate correlations with $R^{2}>0.19$.

the past several thousand years. Conifer/non-arboreal pollen (NAP) ratios from the Twin Lakes site, today situated $\sim 250 \mathrm{~m}$ below the upper elevation limit of Picea, were used to provide a record of past summer temperatures derived from changes in the elevation of the temperature sensitive upper tree line and spruce/pine ratios from the Beef Pasture site were used to create an index of winter precipitation.

Wright (2012) recently recored Beef Pasture creating a highresolution pollen record for the past 2300 years that was constrained by 16 calibrated AMS ${ }^{14} \mathrm{C}$ samples. Wright (2012) used spruce/Pinus ponderosa and sedge/Cheno-am ratios from the Beef Pasture pollen record in an attempt to create low-frequency proxy records of, respectively, temperature and precipitation at this site. Thus Wright (2012) and Petersen (1988) derive two different measures from essentially the same spruce to pine ratio: Wright (2012) derived only temperature, while Petersen (1988) derived effective soil moisture (primarily from winter precipitation). For his winter precipitation measure, Wright (2012) uses the sedge/Chenoam ratios. Unfortunately, sedge is not evenly distributed across the
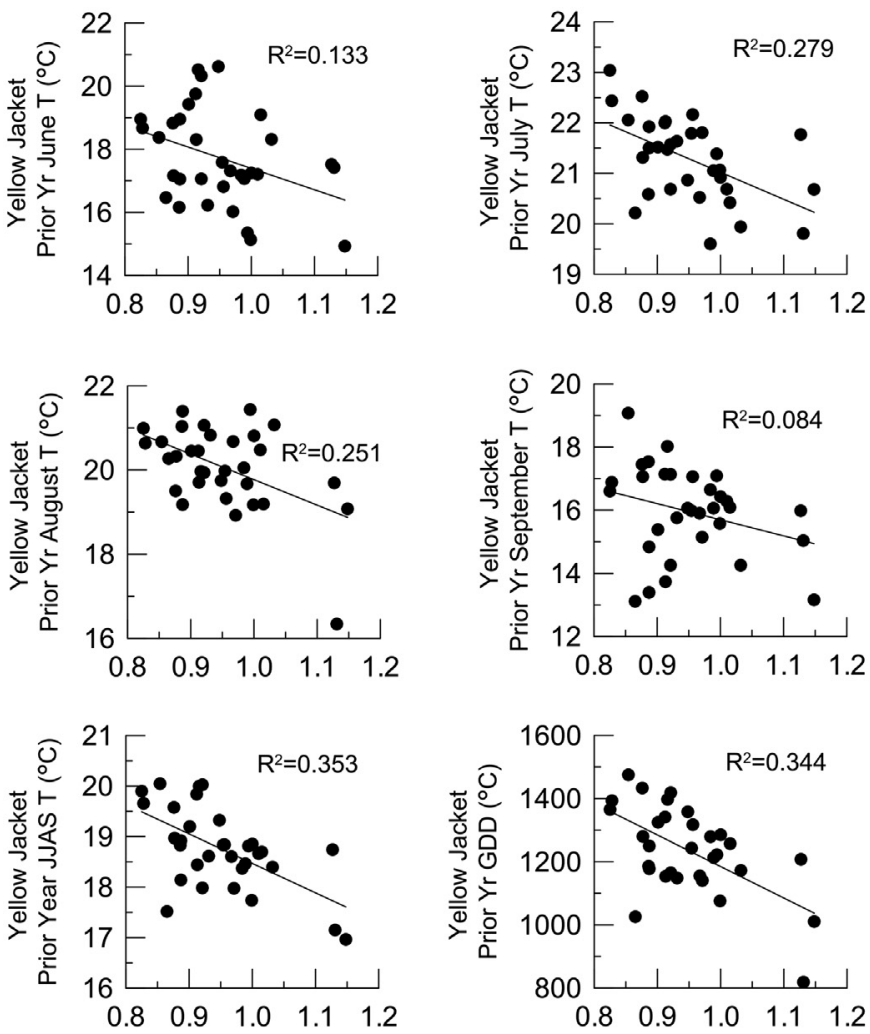

Almagre Standardized Ring Width

(No Prewhitening)

Fig. 5. Yellow Jacket prior-year June, July, August, September, summer (JJAS) temperatures and GDD plotted as a function of Almagre Bristlecone Pine standardized ring widths with no prewhitening of the data. Note that the correlations are negative; i.e. decreasing temperatures occur with increasing ring width, a pattern that makes little sense if tree growth responded positively to warming.

landscape and major changes in sedge percentages occur over short distances; e.g., even though Petersen's (1988) and Wright's (2012) coring sites were only meters apart, the cores contained drastically differing amounts of sedge (compare Cyperaceae in Fig. 3.3 in Wright (2012) with Cyperaceae in Fig. 22 of Petersen (1988)). In addition, Petersen (1988) previously pointed out that increases in spruce pollen in Beef Pasture result from increases in effective soil moisture (a function of increased precipitation and colder temperatures), which is not an indicator of temperature alone as suggested by Wright (2012). Dix and Richards (1976) found that spruce predominates in environments where the snowpack persists longest resulting in greater soil moisture, an observation that supports Petersen's (1988) interpretation of the spruce/pine pollen ratio.

Petersen's (1988) pollen record is neither highly resolved nor is it precisely dated and Wright's (2012) temperature proxy is highly problematic. Thus, for the time being, we do not even have the means of constructing prehistoric low-frequency records of temperature variability, including FFD and GDD, as a function of elevation across southwest Colorado.

\subsection{Model applications}

\subsubsection{Example calculations using the productivity model}

In this example, we assume that $30 \mathrm{~cm}$ represents the minimum amount of water-year precipitation necessary for maize production. We also assume that a Native American family moves to an alluvial soil at an elevation of $1940 \mathrm{~m}$ in A.D. 1200 and clears a 1- 
acre field. In the spring of A.D. 1201, the family plants 440 hills of maize, and selects the four best stalks in each hill after the stalks emerge. In water-year A.D. 1201, Mesa Verde received $51.7 \mathrm{~cm}$ of water-year precipitation (Supplementary Table 1). At $1940 \mathrm{~m}$, the Native American field received 0.83 times the amount of Mesa Verde precipitation (using the linear fit in Fig. 2) or $43 \mathrm{~cm}$. Thus, precipitation was close to optimum for maize production.

In order to determine if there is sufficient $\mathrm{NO}_{3}^{-}$produced in the root frustum to produce $10 \mathrm{bu}$ maize/ac, it is necessary to scale the org- $\mathrm{N}$ mineralization rate to the water-year precipitation amount. Given that most elevations over 2200 will have experienced abbreviated growing seasons in the past, we use values of reconstructed water-year precipitation at Mesa Verde to scale the org-N mineralization rate. Between A.D. 600 and 1300 Mesa Verde precipitation ranged from 13 to $89 \mathrm{~cm}$ and had mean and $1 \sigma$ values of, respectively, 46 and $12 \mathrm{~cm}$. We arbitrarily assign a $2.0 \% / \mathrm{yr}$ mineralization rate to a $70-\mathrm{cm}(2 \sigma)$ water year and a $0.0 \% / \mathrm{yr}$ mineralization rate to a $0-\mathrm{cm}$ water year and further assume that the mineralization rate is a linear function of these two end members; e.g., a 35-cm water year would be associated with a $1.0 \% / \mathrm{yr}$ mineralization rate.

The org-N mineralization rate at the $1940-\mathrm{m}$ field is given by $(43 \mathrm{~cm} / 70 \mathrm{~cm}) \times 2 \% / \mathrm{yr}=1.23 \% / \mathrm{yr}$. A random pick of org- $\mathrm{N}$ from the alluvial soils histogram (Fig. 6) yields a value of $0.05 \%$, only half of which is labile and subject to mineralization. The $1.32 \mathrm{~m}^{3}$ root frustum is assumed to have a density of $1.5 \mathrm{~g} / \mathrm{cm}^{3}$ (mean density of Montezuma County soils; National Resources Conservation Service, 2012). The frustum contains $1.32 \times 10^{6} \mathrm{~cm}^{3} \times 1.5 \mathrm{~g} / \mathrm{cm}^{3}=1.98 \times 10^{6} \mathrm{~g}$ of soil. The soil volume in the frustum contains $1.98 \times 10^{6} \mathrm{~g} \times 0.005 /$ $2=4950 \mathrm{~g}$ of mineralizable org N. Therefore, in A.D. 1201, $0.0123 \times 4950 \mathrm{~g}=60.9 \mathrm{~g}$ of $\mathrm{NO}_{3}^{-}$is produced in the frustum which greatly exceeds the needed $14.8 \mathrm{~g}$ of $\mathrm{NO}_{3}^{-}$. Therefore, the 1 -acre field should yield 10 bu of maize.

In the following year (A.D. 1202), Mesa Verde receives $29.8 \mathrm{~cm}$ of precipitation (Supplementary Table 1) and the Native American field receives $24.7 \mathrm{~cm}$ of precipitation. Crop failure results because $<30 \mathrm{~cm}$ of precipitation was received. However, we still need to keep track of org-N mineralization and its disappearance over time. The mineralization rate is relatively low $(24.7 \mathrm{~cm} / 70 \mathrm{~cm} \times 2 \% /$ $\mathrm{yr}=0.71 \% / \mathrm{yr}$ ). The amount of org-N mineralized in A.D. 1202 is the amount of org-N remaining in the frustum after it's A.D. 1201 loss times its mineralization rate; i.e., $(4950 \mathrm{~g}-60.9 \mathrm{~g}) \times 0.0071=34.7 \mathrm{~g}$ of org N. So the bad news is that the crop failed during the dry year but the good news is that not much org-N was lost from the field.

We also need a means of calculating the useful life of an agricultural field. For the model, the precipitation and org-N mineralization calculations proceed until crop failure becomes routine. We define "useful field life" as the time span during which the amount of org-N in the root frustum is sufficient to support " $n$ " stalks of maize. In our particular example, $14.8 \mathrm{~g}$ of $\mathrm{NO}_{3}^{-}$are necessary to support a density of 4 stalks/hill. By keeping track of the residual org- $\mathrm{N}$ in the root frustum over time, one can also determine when the total org- $\mathrm{N}$ value is nearing its $14.8 \mathrm{~g}$ limiting value (given an average water year). At that time the field would be abandoned and the Native American family would choose a new field site.

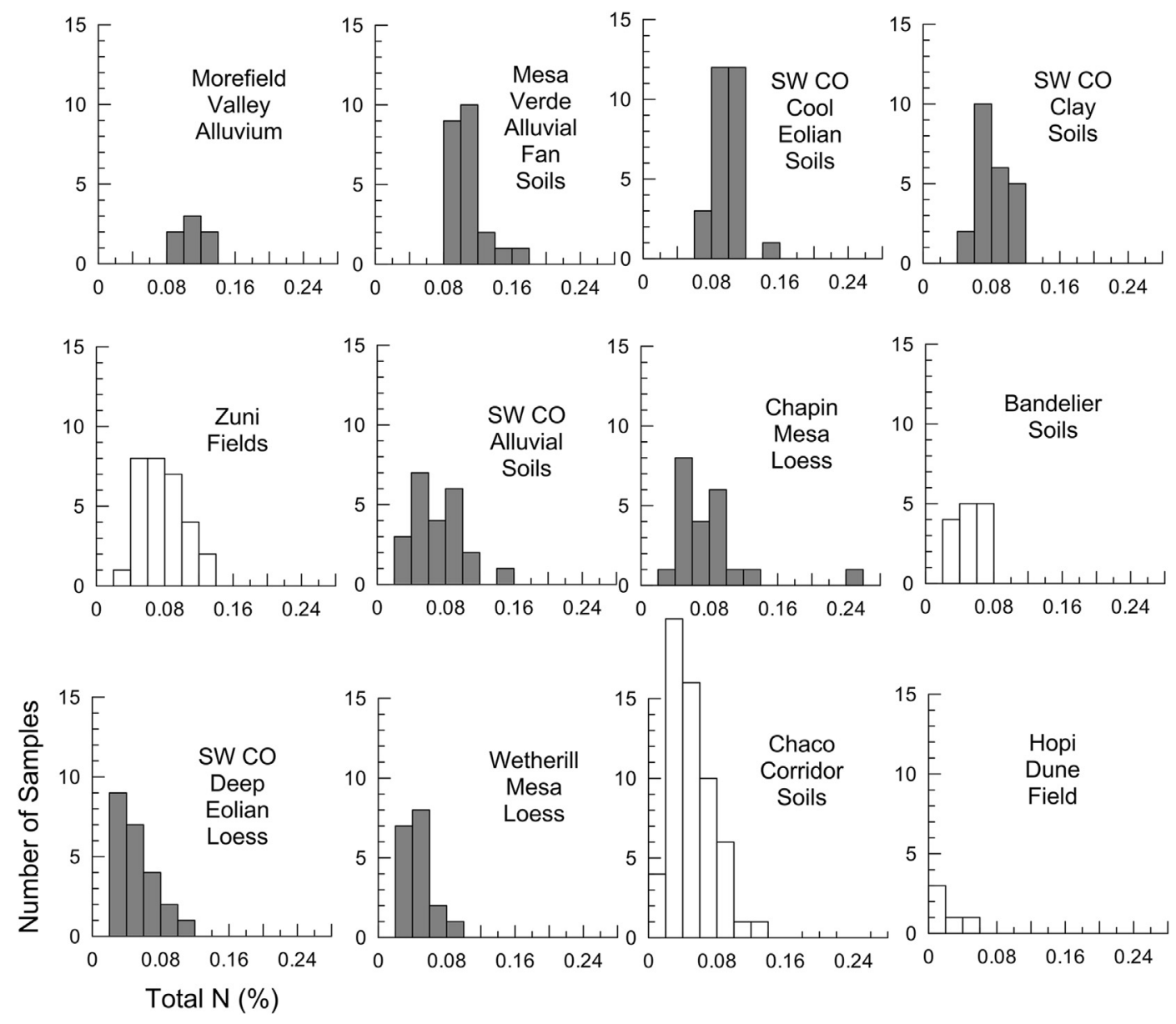

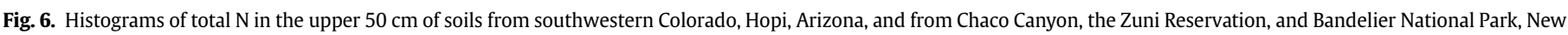
Mexico. Data from southwestern Colorado soils are shown as gray histograms. 


\subsubsection{Changes in the dry-land farming elevation band}

Petersen (1988) previously estimated the low-frequency change in the upper and lower elevations of the prehistoric agricultural belt in southwest Colorado. Petersen (1988) equated historical pollen ratios (conifer/NAP pollen ratios at Twin Lakes and spruce/ pine pollen ratios at Beef Pasture) with, respectively, the observed historic movement of timberline and lower elevation of the spruce forest. A rise in timberline can be associated with an increase in the $10^{\circ} \mathrm{C}$ July isotherm (summer warmth), whereas an increase in the lower elevation of the spruce forest can be equated with a decrease in the winter snowpack. The modern farming belt that is sufficiently wet ( $35 \mathrm{~cm}$ of annual precipitation) and warm (110 FFD) for the growth of bean and maize is relatively narrow with elevational limits of 2010 and $2380 \mathrm{~m}$ in the Dolores area. Petersen (1988) estimated the prehistoric elevation and width of this belt by first comparing historic values of the spruce/pine and conifer/NAP ratios with the elevation limits of historic dry-land farming at certain times and then using prehistoric values of these ratios to approximate the elevation and width of the prehistoric farming belt. In the following, we present a new method for determining high-frequency (interannual) change in the lower elevation limit of prehistoric maize agriculture as well as the elevation of optimum prehistoric maize production in southwest Colorado.

The upper and lower limits of maize farming changed over time as a function of precipitation, FFD, and GDD. Unfortunately we are unable to approximate past values of the latter two parameters in this paper. However, a fit of water-year precipitation as a function of elevation (Fig. 3, Table 1) allows us to approximate the elevation of past water-year precipitation contours as a function of time.

We first calculate the present-day elevations of the 30- and 50$\mathrm{cm}$ precipitation contours. In this calculation, the $30-\mathrm{cm}$ contour represents the lower limit of precipitation necessary for the production of maize and the $50-\mathrm{cm}$ contour represents the approximate optimum value of precipitation necessary for the production of maize. Substituting the two precipitation values in the linear fit depicted in Fig. 3 yields present-day elevations of 1732 and 2175 m, respectively, for the 30 - and $50-\mathrm{cm}$ contours. ${ }^{1}$ These values indicate that for every $1-\mathrm{cm}$ increase in precipitation, a particular precipitation contour decreases $22.2 \mathrm{~m}$ in elevation and vice versa. We then calculate the prehistoric annual elevations of the 30- and 50$\mathrm{cm}$ contours given the historic Mesa Verde (MV) precipitation value of $49.3 \mathrm{~cm}$ and the reconstructed prehistoric Mesa Verde precipitation value, using the following three equations:

Prehistoric MV precipitation $-49.3 \mathrm{~cm}$

$=\mathrm{N} \mathrm{cm}$ (past change in MV precipitation);

$$
\begin{aligned}
& \text { If } \mathrm{N}>0, \mathrm{Y}=\mathrm{N} \times 22.2 \text { and elevation of } 30-\mathrm{cm} \text { contour } \\
& \quad=1732-\mathrm{Y}
\end{aligned}
$$

\section{If $\mathrm{N}<0, \mathrm{Y}=\mathrm{N} \times 22.2$ and elevation of $30-\mathrm{cm}$ contour} $=1732+\mathrm{Y}$;

To determine the elevation of the $50-\mathrm{cm}$ precipitation contour, 2175 is substituted for 1732 in the previous equations.

Fig. 3 displays how the 30 -cm precipitation contour changes in elevation with a $10-\mathrm{cm}$ increase in Mesa Verde precipitation; i.e., the precipitation-elevation linear fit shifts vertically $10 \mathrm{~cm}$ along the precipitation axis and the intersection of the shifted line with

\footnotetext{
${ }^{1}$ Note that these elevations differ slightly from those calculated using the fit to weather station multiples of Mesa Verde precipitation shown in Fig. 2.
}

the $30-\mathrm{cm}$ precipitation value determines the new elevation of the 30 -cm contour ( $1510 \mathrm{~m})$.

In Figs. 7 and 8, the elevational limits of the Great Sage Plain (1500-2100 $\mathrm{m}$ ) and the modern farming belt (2010-2380 m) have been bounded, respectively, by rectangles with dashed and solid lines. Some have suggested that the Great Sage Plain functioned as the "bread basket" of the Anasazi that inhabited southwestern Colorado. Fig. 7 depicts the elevation of the 30-cm water-year contour for the period A.D. 600 to 1350. The data enclosed in dark gray have been smoothed with a $3-\mathrm{yr}$ running average. The thick white line represents a $21-\mathrm{yr}$ running average of the data, which is used to outline persistent wet and dry phases of the record. Note the presence of the A.D. 1130-1180 (middle-12th century), and the A.D. $1276-1300$ (late-13th century) droughts in the record. In general the Great Sage Plain would have produced some maize during $89 \%$ of the period of record. However, the mid-12th century megadrought was particularly intense with several years in which maize would have had to be grown above $2200 \mathrm{~m}$, an elevation generally associated with a very short growing season.

The plot of the 50-cm water-year contour (Fig. 8) indicates, that during only $33 \%$ of the time, could an optimum crop of maize been produced within the elevational range of the Great Sage Plain and that $23 \%$ of the time the $50-\mathrm{cm}$ contour lay above the upper elevation range of the modern dry-land farming belt.

The question arises "how would have prehistoric Native Americans responded to the interannual variability of precipitation?" Fig. 9 indicates the absolute value of the interannual difference in any precipitation contour for southwest Colorado between A.D. 600 and 1350 . The mean and median values of the interannual change in elevation of a particular contour are, respectively, 287 and $231 \mathrm{~m}$. Thus, more than $50 \%$ of the time, the elevation of the $30-\mathrm{cm}$ precipitation contour would shift more than $231 \mathrm{~m}$ either up or down within a year. We suggest that, in general, it was difficult to predict either the direction or magnitude in the shift of annual precipitation. However, the depth and areal extent of winter snowpack might have been used as a rough indicator of spring soil moisture. In addition, successive series of anomalously wet or dry years might also have provided insight as to the probable lower elevation limit of agricultural productivity. However, to be on the safe side, Native Americans would have had to generally farm at upper elevations where agriculture was mostly limited by the length and intensity of

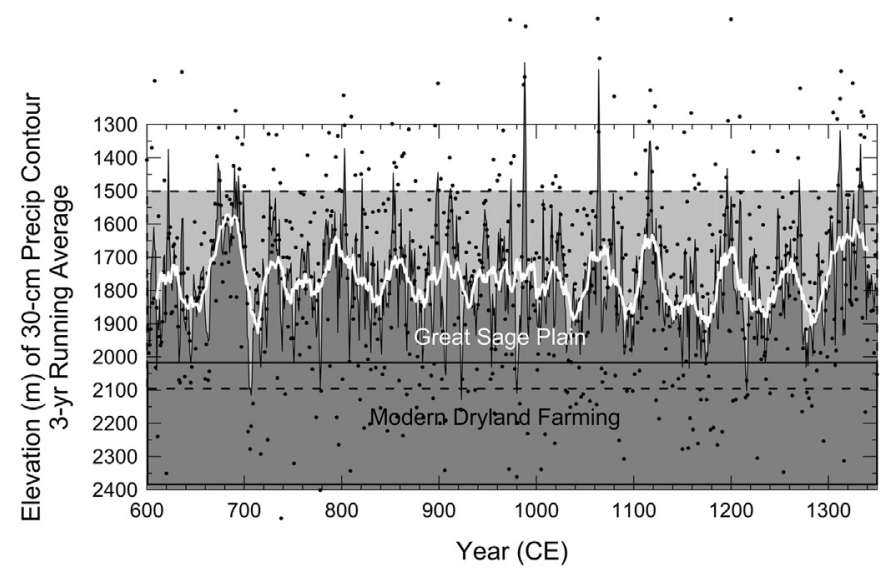

Fig. 7. Elevation of the $30-\mathrm{cm}$ water-year precipitation contour for the period A.D. $600-1350$. The data enclosed in dark gray have been smoothed with a 3-yr running average. The thick white line represents a 21-yr running average of the data, which is used to outline persistent wet and dry phases of the record. The Great Sage Plain lies between elevations of 1500 and $2100 \mathrm{~m}$ and the region of modern dry-land farming in the Dolores area lies between 2010 and $2380 \mathrm{~m}$. 


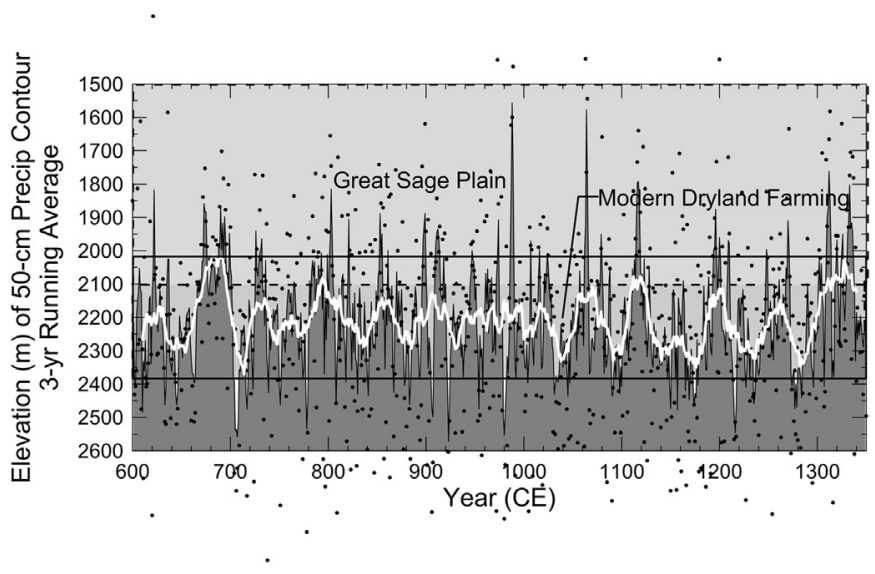

Fig. 8. Elevation of the $50-\mathrm{cm}$ water-year precipitation contour for the period A.D. 600-1350. The data enclosed in dark gray have been smoothed with a 3-yr running average. The thick white line represents a 21-yr running average of the data, which is used to outline persistent wet and dry phases of the record. The Great Sage Plain lies between elevations of 1500 and $2100 \mathrm{~m}$ and the region of modern dry-land farming in the Dolores area lies between 2010 and $2380 \mathrm{~m}$.

the summer growing season and (or) they would have had to scatter their fields over a range in elevations in response to the variability in interannual precipitation.

Petersen (1988) found that the tree line had risen during the past 150 years in the LaPlata Mountains, suggesting an increase in regional air temperature. If the past GDD profile during warm (dry) periods with elevation was similar to the present-day profile (Fig. 4B), elevations above $2200 \mathrm{~m}$ would have received $<1000$ GDD, a value that may represent the minimum for the production of maize. This suggests that, in general, elevations above $2200 \mathrm{~m}$ were not suitable for prehistoric agriculture during most of the time.

\subsection{Future improvements to the model}

\subsubsection{Some limited ways of dealing with the effect of temperature} on the growing season

At this point in time, it appears that the amount of heat impacting maize at any particular field site in southwestern Colorado is a complicated function of solar radiation and the topography of the landscape, which in some cases leads to the pooling of cold air (e.g., Ignacio, Colorado) and, in other situations, leads to increased levels of heating (e.g., Mesa Verde) (see Fig. 4). Presentday land-surface temperature and soil moisture measurements of southwestern Colorado could be obtained, using satellite-based

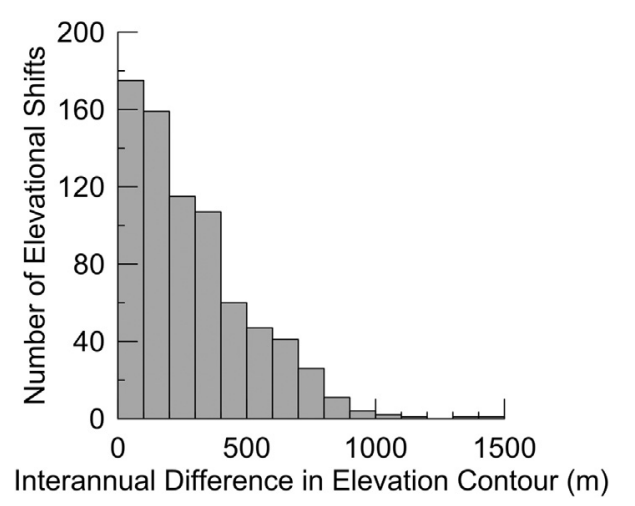

Fig. 9. Histogram depicting interannual shifts in the elevations of the $30-\mathrm{cm}$ contour in southwestern Colorado. instrumentation in combination with surface-based temperature and soil-moisture sensors (see, e.g., Holmes, et al., 2011). If such measurements were made using a sufficiently small grid area, they could be used to identify areas routinely impacted by cold air pooling. Those areas could then be ruled out as potential field sites.

We suggest that the upper boundary of present-day dry-land farming $(2380 \mathrm{~m})$ represents a maximum limit of maize production during prehistoric periods of relative warmth; e.g., most of the weather stations indicate a weak but negative association of GDD with water-year precipitation (Fig. 10). This suggests the upper limit of maize production fell during times of increased moisture availability. Given that most of the historical period (1919-1982) used to define the upper limit of the dry-land farming belt (Petersen, 1987a) was in drought (Fig. 11) and was substantially warmer on average (Petersen, 1988), we would expect the upper limit of maize production to have fallen below the $2380 \mathrm{~m}$ boundary during prehistoric wet periods.

\subsubsection{Other potential low-frequency records of climate change}

With respect to low-frequency records of climate change, shallow lakes suitable for pollen-based or other proxy temperature reconstructions exist not only in the Twin Lakes region northwest of Durango but also on the Mogollon Rim of the Colorado Plateau. For example, Anderson (1993) performed a low-resolution pollen study of sediments from Potato Lake, Arizona, where the upper $75 \mathrm{~cm}$ of sediment yielded a climate record for the past 3500 years. A $0.5-\mathrm{cm}$ continuous sampling of the upper part of such a core would yield a 25 -year resolution of late-prehistoric climate change.

A record of climate change for the past 2000 years is contained within the top $90 \mathrm{~cm}$ of sediment of Twin Lakes sediments (Petersen and Mehringer, 1976); thus, if another core was collected from this site and sampled continuously over $0.5-\mathrm{cm}$ intervals, a $10-$ yr resolution of late-prehistoric climate change would result.

Although the use of alkenones to reconstruct past lake-water temperatures is still in its infancy (see, e.g., Theroux et al., 2010), it may, in the future, be possible to obtain prehistoric records of lake temperature change from some of the southwestern U.S. lakes. This organic marker has been successfully applied to marine sedimentary sequences (see, e.g., Barron et al., 2003).

\subsubsection{Estimates of summer rainfall}

One substantial parameter missing from our model is summer (monsoonal) precipitation. Griffin et al. (2011) and Meko and Baisan (2001) have demonstrated some success in using conifer latewood widths to retrodict past regional summer precipitation amounts and Leavitt et al. (2011) have shown that the carbon isotope content of tree rings also has potential in determining the strength of the summer monsoon in the American Southwest. Such studies would greatly benefit the understanding of prehistoric maize productivity in southwestern Colorado.

\subsubsection{Tapering of maize yields with reductions in precipitation and available $\mathrm{NO}_{3}^{-}$}

In our model, total crop loss occurred when there was $<30 \mathrm{~cm}$ of water-year precipitation and $<14.8 \mathrm{~g} \mathrm{NO}_{3}^{-}$produced in the root frustum (4-stalk condition). When these limiting values were met or exceeded, $10 \mathrm{bu} / \mathrm{ac}$ of maize was produced. In reality, nutrient and water stress probably begins to take effect prior to the limiting value is reached. One way to deal with this would be to produce yield functions that decrease with decreasing water-year precipitation and $\mathrm{NO}_{3}^{-}$produced in the root frustum. Fig. $12 \mathrm{~A}$ and $\mathrm{B}$ illustrate examples of such functions. Response of maize yields to precipitation and to loss of org- $\mathrm{N}$ could be provided via experimental maize gardens that were cultivated for two or more decades. 

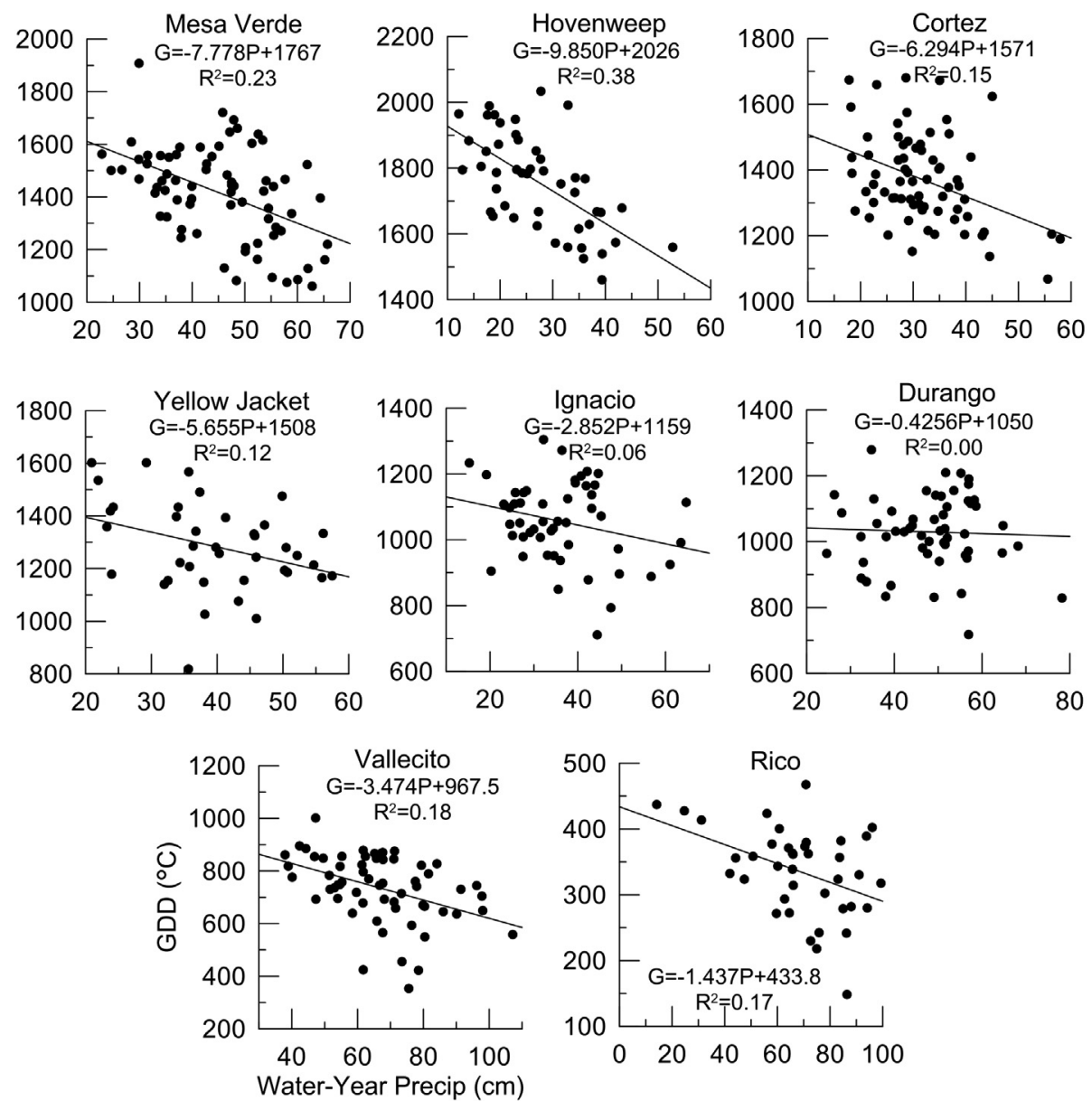

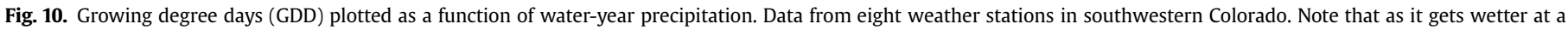
particular station, it generally gets cooler.

\subsubsection{Soil density}

In the calculation of a soil's org-N concentration, a soil density of $1.5 \mathrm{~g} / \mathrm{cm}^{3}$ was used. In fact, soil density varies widely with soil type and soil depth; e.g., 133 samples taken from Montezuma county soils have densities ranging from 0.34 to $2.18 \mathrm{~g} / \mathrm{cm}^{3}$ with mean and $1 \sigma$ values of 1.54 and $0.24 \mathrm{~g} / \mathrm{cm}^{3}$ (National Resources Conservation Service, 2012). Such data could be used to better approximate the

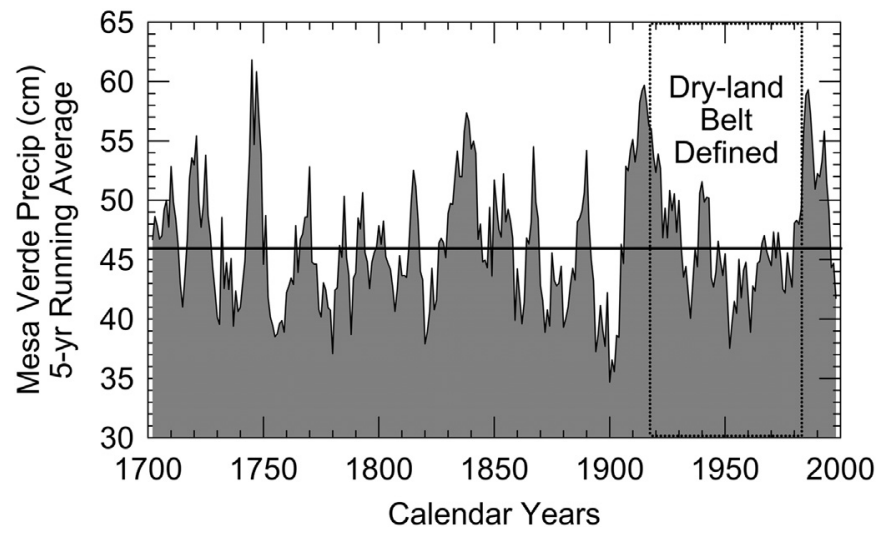

Fig. 11. A five-year running average of reconstructed Mesa Verde precipitation between A.D 1700 and 2000. The rectangle bounded by a dotted line is the time period (1919-1982) over which the dry-land farming belt was defined. This was a generally dry period. range of soil densities associated with each of the seven productive soil groups (Table 2; Supplementary Table 3).

\subsection{6. $\mathrm{NO}_{3}^{-}$loss from the root volume}

In the calculation of org- $\mathrm{N}$ mineralization, it was assumed that all $\mathrm{NO}_{3}^{-}$produced in the root frustum was available to the maize's root system. This is probably not the case as $\mathrm{NO}_{3}^{-}$is highly mobile and can be flushed out of the root zone by infiltrating precipitation. If we assume that the soil is at or below its field capacity at the time of planting, then the $\mathrm{NO}_{3}^{-}$produced during the mineralization
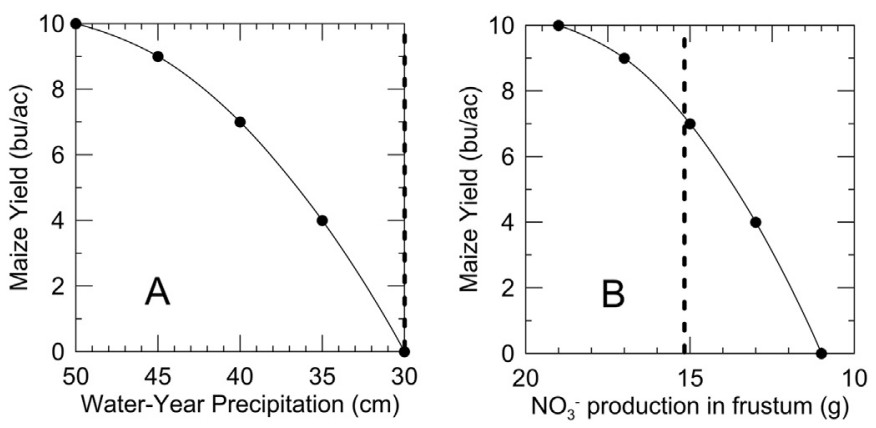

Fig. 12. Hypothetical maize yields as a function of $A$. water-year precipitation and $B$. Nitrate production in the root zone frustum. Vertical lines indicate limiting values for maize production. 
process will be confined to capillary soil water and will thus be available to the root system. However, if a summer storm should cause the rapid infiltration of rain water, then the $\mathrm{NO}_{3}^{-}$captured by the infiltrating water will advect through the soil column and may pass below the root system. Arbuscular mycorrhizal fungi can greatly increase the absorbing surface area of the root. The fungal hyphae can increase the effective volume of the root frustum in that the hyphae can extend between 3 and $7 \mathrm{~cm}$ beyond the nitrogen depletion zone that normally develops within the root frustum (Rakshit and Bhadoria, 2008).

This process is exacerbated by the fact that the root system takes about four weeks to reach its maximum depth (see Section 2.4); thus, early summer rains may remove $\mathrm{NO}_{3}^{-}$from the deeper parts of the mature root frustum before the roots reach such depths. To model this process, one needs to know if the soil is at or below its field capacity in the early spring and also the frequency, duration and intensity of summer rains. Because winter precipitation is often highly correlated with the ring width of trees such as Douglas fir, the calculation of field capacity is doable; however, there are no proxies for summer precipitation let alone the frequency, duration and intensity of summer precipitation. Therefore, the parameterization of $\mathrm{NO}_{3}^{-}$residence time in the root zone would probably have to be done in a somewhat arbitrary manner. Experiments involving the emplacement of lysimeters in the soil zone could be used to understand the flux of water and $\mathrm{NO}_{3}^{-}$from the soil zone over the annual cycle, thus enabling calculations of the efficiency of root absorption of $\mathrm{NO}_{3}^{-}$.

\subsubsection{Scaling of org- $N$ mineralization rate with water-year precipitation}

Previously we assigned a $2.0 \% / \mathrm{yr}$ org- $\mathrm{N}$ mineralization rate to a $70-\mathrm{cm}$ water year and a $0.0 \% / \mathrm{yr}$ mineralization rate to a $0-\mathrm{cm}$ water year. Given that most of the data on org-N and org-C mineralization rates indicate values $<1 \% / \mathrm{yr}$ (Table 4 ) and that most of the values were obtained from relative wet and humid regions, a mineralization rate of $1 \% / \mathrm{yr}$ for a $70-\mathrm{cm}$ precipitation rate may be more appropriate. Again, field experiments in which the amount of org- $\mathrm{N}$ and $\mathrm{NO}_{3}^{-}$in the soil and the flux of $\mathrm{NO}_{3}^{-}$from the soil are measured after the field is cleared and not planted would allow calculation of org-N mineralization rates for southwestern Colorado soils.

\section{Summary and conclusions}

We have presented a relatively simple method for the calculation of prehistoric water-year precipitation throughout the southwestern Colorado study area as a function of time and elevation. Prehistoric water-year precipitation values for Mesa Verde together with a modern-day elevation-dependent precipitation function allowed us to determine the approximate elevations of southwest Colorado precipitation contours for each year since A.D. 480, including the $30-\mathrm{cm}$ contour, which represents the minimum amount of precipitation necessary for the production of maize and the 50-cm contour, which represents the optimum amount of precipitation necessary for the production of maize.

We found that the Great Sage Plain (elevation 1500-2100 m) would have produced some maize during $89 \%$ of the time between A.D. 600 and 1350. However, the mid-12th century megadrought was particularly intense, containing several years in which maize would have had to be grown above $2200 \mathrm{~m}$, an elevation associated with a very short growing season. The plot of the $50-\mathrm{cm}$ water-year contour indicates that during only $33 \%$ of the time could an optimum crop of maize been produced within the elevation range of the Great Sage Plain and that $23 \%$ of the time the $50-\mathrm{cm}$ contour lay above the upper elevation range $(2380 \mathrm{~m})$ of the modern dry-land farming belt. We also found that more than $50 \%$ of the time, the elevation of the $30-\mathrm{cm}$ precipitation contour would have shifted more than $231 \mathrm{~m}$ either up or down within a single year. This suggests that prehistoric Native Americans would have had to generally farm at upper elevations where agriculture was mostly limited by the length and intensity of the summer growing season and (or) they would have had to scatter their fields over a range in elevations in response to the variability in interannual precipitation. If space permitted, the former strategy would have been preferable.

We also presented simple approaches to calculations of maize yield and field life as a function of precipitation and soil group, wherein each soil group is associated with a previously measured org-N distribution. In the future, as human population data become available as a function of space and time, one test of the model would be to plot the elevation and locations of prehistoric Native American villages over time and compare that plot with plots of the $30-$ and $50-\mathrm{cm}$ water-year precipitation contours with time.

We believe the model of maize productivity presented in this paper represents a substantial improvement relative to the existing VEP maize productivity approach and we look forward to its future testing and improvement.

\section{Acknowledgments}

Much of this research was supported by the National Science Foundation under grant DEB-0816400 (Benson) and NOAA grant number NA08OAR4310727 (Stahle). This work supports the Village Ecodynamics Project (VEP) whose objectives include agent-based modeling of the interactions between prehistoric Native Americans who occupied the Four Corners region of the American Southwest, the landscape they occupied, and the climate that impacted the region during the late-thirteenth century. The authors thank Matthew Salzer for access to tree-ring-width data from San Francisco Peaks Bristlecone Pines and to Connie Woodhouse and Jeffrey Lukas for access to updated tree-ring-width data from the Almagre Mountain Bristlecone Pines. The Almagre Mountain C chronology was compiled by Craig Brunstein, using his new collection through 1994, plus D. Graybill's collection through 1983, and V. LaMarche's original chronology through 1968. Daniel Griffin was instrumental in measuring the Douglas fir ring widths and Dorian J. Burnette contributed to the statistical analyses. Stefani Crabtree created Supplementary Fig. 1. Jim Ashby, formerly with the Western Regional Climate Center, went beyond the call of duty to create the historical FFD data sets for the eight weather stations. Timothy Kohler reviewed earlier versions of this manuscript and made a number of excellent suggestions regarding its improvement. Eleanor Griffin was responsible for many of the soil elevation calculations. Thanks also to three anonymous reviewers and William Lipe for their suggestions on how the manuscript could be improved.

\section{Appendix A. Supplementary data}

Supplementary data related to this article can be found at http:// dx.doi.org/10.1016/j.jas.2013.03.013.

\section{References}

Anderson, R.S., 1993. A 35,000 year vegetation and climate history from Potato Lake, Mogollon Rim, Arizona. Quaternary Research 40, 351-359.

Ayers, R.S., 1977. Quality of water for irrigation. Journal of Irrigation and Drainage Division 103, 135-154.

Barron, J.A., Heusser, L., Herbert, T., Lyle, M., 2003. High-resolution climatic evolution of coastal northern California during the past 16,000 years. Paleoceanography 18, 1020. http://dx.doi.org/10.1029/2002PA000768.

Bellorado, B.A., 2007. Breaking Down the Models: Reconstruction Prehistoric Subsistence Agriculture in the Durango District of Southwestern Colorado. M.A. dissertation. Northern Arizona University, Flagstaff. 
Benson, L.V., Berry, M.S., 2009. Climate change and cultural response in the prehistoric American Southwest. Kiva 75, 89-119.

Benson, L.V., 2010a. Factors controlling pre-Columbian and early historic maize productivity in the American southwest, Part 2: the Chaco Halo, Mesa Verde, Pajarito Plateau/Bandelier, and Zuni archaeological regions. Journal of Archaeological Method and Theory 18, 61-109.

Benson, L.V., 2010b. Factors controlling pre-Columbian and early historic maize productivity in the American southwest, Part 1: the southern Colorado Plateau and Rio Grande regions. Journal of Archaeological Method and Theory 18, 1-60.

Bradfield, M., 1971. The Changing Pattern of Hopi Agriculture. Royal Anthropological Institute. Occasional Paper No. 30.

Briffa, K.R., Osborn, T.J., Schweingruber, F.H., Farris, I.C., Jones, P.D., Shiyatov, S.G., Vaganov, E.A., 2001. Low-frequency temperature variations from a northern tree ring density network. Journal of Geophysical Research 106, 2929-2941.

Burns, B.T., 1983. Simulated Anasazi Storage Behavior Using Crop Yields Reconstructed from Tree Rings. Ph.D. dissertation. University of Arizona, Tucson.

Clay, D.E., Clapp, C.E., Reese, C., Liu, Z., Carlson, C.G., Woodward, H., Bly, A., 2007. Carbon-13 fractionation of relic soil organic carbon during mineralization effects calculated half-lives. Soil Science Society of America Journal 71, 1003-1009.

Dix, R.L., Richards, J.L., 1976. Possible change in spectra structure of the subalpine forest induced by increased snowpack. In: Steinhoff, H.W., Ives, J.D. (Eds.), Ecological Impacts of Snowpack Augmentation in the San Juan Mountains, Colorado. Ecology Project Final Report, Colorado State University, Fort Collins, pp. 311-322.

Doran, J.W., Elliot, E.T., Paustian, K., 1998. Soil microbial activity, nitrogen cycling, and long-term changes in organic carbon pools as related to fallow tillage management. Soil Tillage Research 49, 3-18.

Dwyer, L.M., Ma, B.L., Stewart, D.W., Hayhoe, H.N., Bachin, D., Culley, J.L.B., McGovern, M., 1996. Root mass distribution under conventional and conservation tillage. Canadian Journal of Soil Science 76, 23-28.

Fehrenbacher, J.B., Rust, R.H., 1956. Corn root penetration in soils derived from various textures of Wisconsin-age glacial till. Soil Science 82, 369-378.

Griffin, D., Meko, D.M., Touchan, R., Leavitt, S.W., Woodhouse, C.A., 2011. Latewood chronology development for summer-moisture reconstruction in the US Southwest. Tree-ring Research 67, 87-101.

Hanway, D.G., 1966. Irrigation. In: Pierre, W.H. (Ed.), Advances in Corn Production: Principles and Practices. Iowa State University Press, Ames, pp. 155-176.

Herrmann, A., 2003. Predicting Nitrogen Mineralization from Soil Organic Matter a Chimera?. Ph.D. dissertation Swedish University of Agricultural Sciences, Uppsala.

Hoeft, R.G., Peck, T.R., 2002. Soil testing and fertility. In: Hoeft, R.G., Nafziger, E. (Eds.), The Illinois Agronomy Handbook. University of Illinois Extension, Urbana-Champaign, pp. 91-131.

Holmes, T., Crow, W., Jackson, T., 2011. Development of a Continuous Multi-satellite Land Surface Temperature Product. U.S. Department of Agriculture. Beltsville Agricultural Research Center Poster Day, Abstract 15.

Jenkins, M.T., 1941. Influence of climate and weather on growth of corn. In: Hambidge, G. (Ed.), Climate and Man, Yearbook of Agriculture, 1941. U.S. Department of Agriculture, Washington, D.C., pp. 308-341.

Jenkinson, D.S., Rayner, J.H., 1977. The turnover of soil organic matter in some of the Rothamsted classical experiments. Soil Science 123, 298-305.

Kohler, T.A., 2012. Modeling agricultural productivity and farming effort. In: Kohler, T.A., Varien, M.D. (Eds.), Emergence and Collapse of Early Villages, Models of Central Mesa Verde Archaeology. University of California Press, Berkeley, pp. 85-112.

Kohler, T.A., Bocinsky, R.K., Cockburn, D., Crabtree, S.A., Varien, M.D., Kolm, K.E., Smith, S., Ortman, S.G., Kobti, Z., 2012. Modelling prehispanic Pueblo societies in their ecosystems. Ecological Modelling 241, 30-41.

Leavitt, S.W., Woodhouse, C.A., Castro, C.L., Wright, W.E., Meko, D.M., Touchan, R., Griffin, D., Ciancarelli, B., 2011. The North American monsoon in the US Southwest: potential for investigation with tree-ring carbon isotopes. Quaternary International 235, 101-107.

Leonard, W.H., Brandon, J.F., Curtis, J.J., 1940. Corn Production in Colorado. In: Colorado Experiment Station Bulletin 463. Fort Collins.

Meko, D.M., Baisan, C.H., 2001. Pilot study of latewood-width of conifers as an indicator of variability of summer rainfall in the North American Monsoon region. International Journal of Climatology 21, 697-708.

Muenchrath, D.A., Kuratomi, M., Sandor, J.A., Homburg, J.A., 2002. Observational study of maize production in semiarid New Mexico. Journal of Ethnobiology 22, $1-33$.

National Resources Conservation Service, 2012. http://soils.usda.gov/.
Nielson, R.L., 2012. Drought and Heat Stress Effects on Corn Pollination. http://www agry.purdue.edu/ext/corn/news/articles.96/p\&c9635.htm (accessed 12.07.12.)

Petersen, K.L., 1987a. Tree-ring transfer functions for estimating corn production. In: Petersen, K.L., Orcutt, J.D. (Eds.), Dolores Archaeological Program: Supporting Studies: Settlement and Environment. United States Department of the Interior, Bureau of Reclamation Engineering and Research Center, Denver pp. 217-231.

Petersen, K.L., 1987b. Reconstruction of droughts for the Dolores project area using tree-ring studies. In: Petersen, K.L., Orcutt, J.D. (Eds.), Dolores Archaeological Program: Supporting Studies: Settlement and Environment. United States Department of the Interior, Bureau of Reclamation Engineering and Research Center, Denver, pp. 91-102.

Petersen, K.L., 1988. Climate and the Dolores River Anasazi. University of Utah. Anthropological Papers No. 113.

Petersen, K.L., 1994. A warm and wet little climatic optimum and a cold and dry Little Ice Age in the southern Rocky Mountains, U.S.A. Climatic Change 26, $243-$ 269.

Petersen, K.L., Mehringer Jr., P.J., 1976. Postglacial timberline fluctuations, LaPlata Mountains, southwestern Colorado. Arctic and Alpine Research 8, 275-288.

Qin, R., Stamp, P., Richner, W., 2006. Impact of tillage on maize rooting in a Cambisol and Luvisol in Switzerland. Soil \& Tillage Research 85, 50-61.

Rakshit, A., Bhadoria, P., 2008. Measurement of arbuscular mycorrhizal hyphal length and prediction of $\mathrm{P}$ influx by mechanistic model. World Journal of Agricultural Sciences 4, 23-27.

Ramsey, D.K., 1997. Soil Survey of Cortez Area, Colorado, Parts of Dolores and Montezuma Counties. United States Department of Agriculture, Natural Resources Conservation Service.

Salzer, M.W., Kipfmueller, K.F., 2005. Reconstructed temperature and precipitation on a millennial timescale from tree-rings in the southern Colorado Plateau, U.S.A. Climatic Change 70, 465-487.

Shaw, R.H., 1988. Climate requirement. In: Sprague, G.F., Dudley, J.W. (Eds.), Corn and Corn Improvement, third ed. American Society of Agronomy, Madison, pp. 609-638.

Soudi, B., Sbai, A., Chiang, C.N., 1990. Nitrogen mineralization in semiarid soils of Morocco: rate constant variation with depth. Soil Science Society of America Journal 54, 756-761.

Theroux, S., D'Andrea, W.J., Toney, J., Amaral-Zettleer, L., Huang, Y., 2010. Phylogenetic diversity and evolutionary relatedness of alkenones-producing haptophyte algae in lakes: implications for continental paleotemperature reconstructions. Earth and Planetary Science Letters 300, 311-320.

Thomison, P., Lipps, P., Hammond, R., Mullen, R., Eisley, B., 2012. Ohio Agronomy Guide, fourteenth ed.. Bulletin 472-05. http://ohioline.osu.edu/b472/0005.htm (accessed 13.07.12.).

Van West, C.R., 1994. Modeling Prehistoric Climatic Variability and Agricultural Production in Southwestern Colorado: a GIS Approach. In: Reports of Investigations 67. Washington State University Department of Anthropology Pullman.

Weaver, J.E., 1926. Root Development of Field Crops. McGraw-Hill Book Company, London.

Western Regional Climate Center. http://www.wrcc.dri.edu/, last accessed July 2012.

Williams, M.A., Rice, C.W., Owensby, C.E., 2000. Carbon dynamics and microbial activity in tallgrass prairie exposed to elevated $\mathrm{CO}_{2}$ for 8 years. Plant Soil 227 127-137.

Wright, A.M., 2012. Low-frequency climate in the Mesa Verde region. In: Kohler, T.A., Varien, M.D. (Eds.), Emergence and Collapse of Early Villages, Models of Central Mesa Verde Archaeology. University of California Press, Berkeley, pp. $41-57$.

\section{Further readings}

Dean, J.S., Robinson, W.S., 1978. Expanded Tree-ring Chronologies for the Southwestern United States. In: Chronology Series, vol. 3. Laboratory of Tree-Ring Research, University of Arizona, Tucson.

Honeycutt, L., 1995. Dryland gardening in southwest Colorado: past and present. In: Toll, H.W. (Ed.), Soil, Water, Biology, and Belief in Prehistoric and Traditional Southwestern Agriculture. New Mexico Archaeological Council Special Publication, No. 2, Albuquerque, pp. 369-373.

World Data Center for Paleoclimatology, 2003. http://hurrican.ncdc.noaa.gov/pls/ paleo (accessed 03.03.03.). 


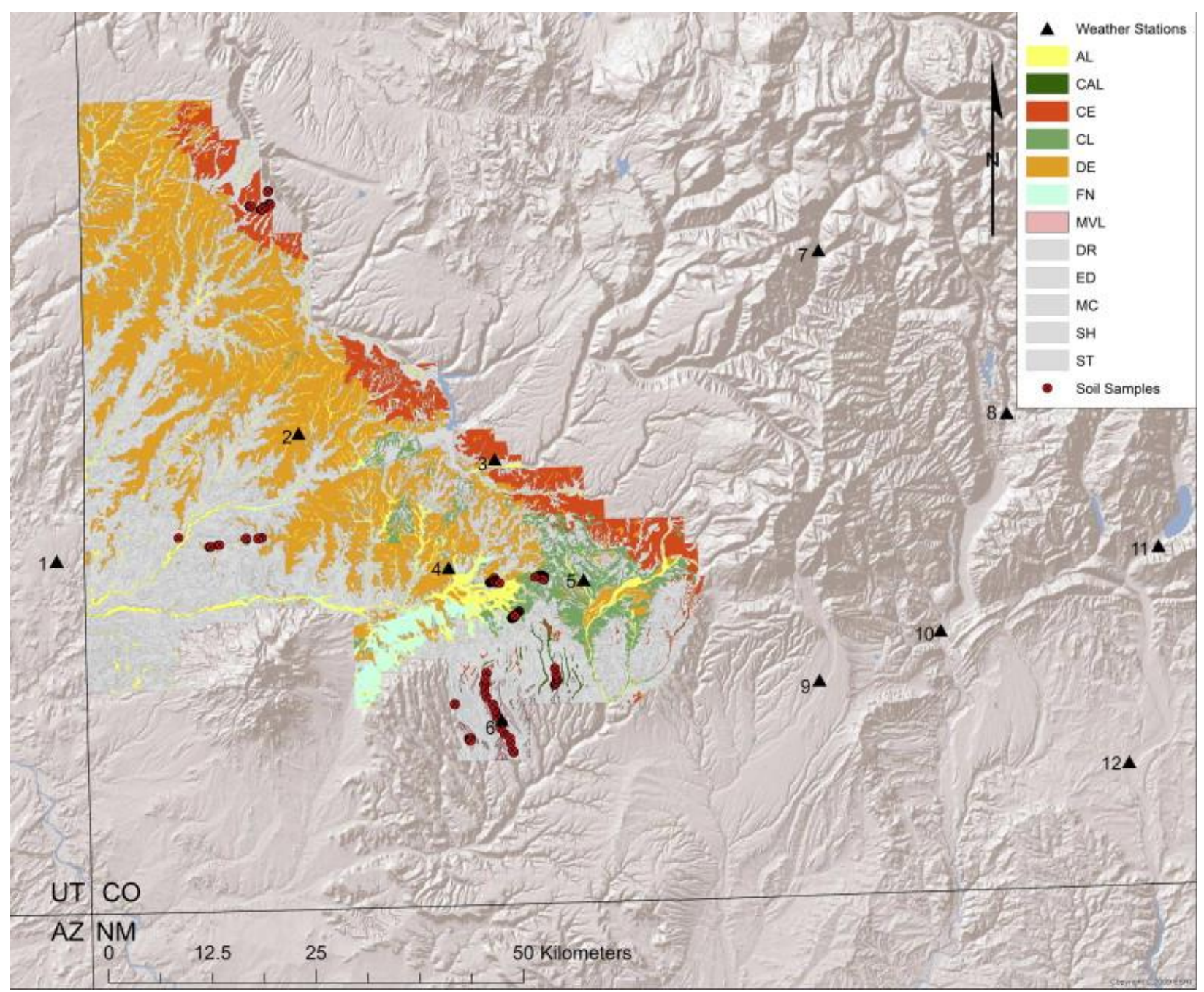

Supplementary Fig. S1.

Distribution of seven soil groups suitable for farming and five soil groups that unsuitable for farming in southwestern Colorado. Soil sampling sites are shown as red dots; weather station sites are shown as black triangles. 

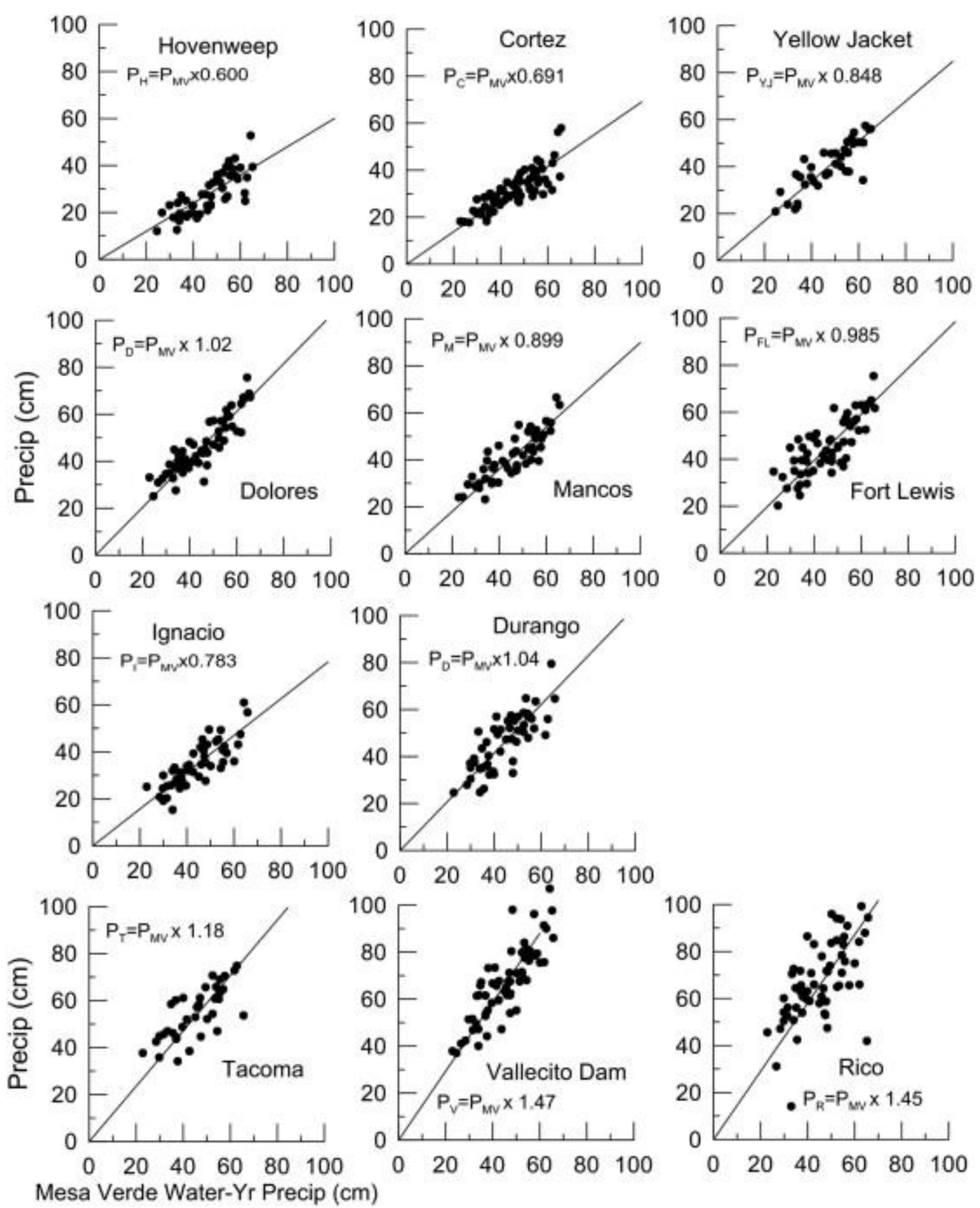

Supplementary Fig. S2.

Correlations of Mesa Verde water-year precipitation with water-year precipitation from 11 weather stations in southwestern Colorado. All regressions have been forced to pass through $x=0, y=0$. 

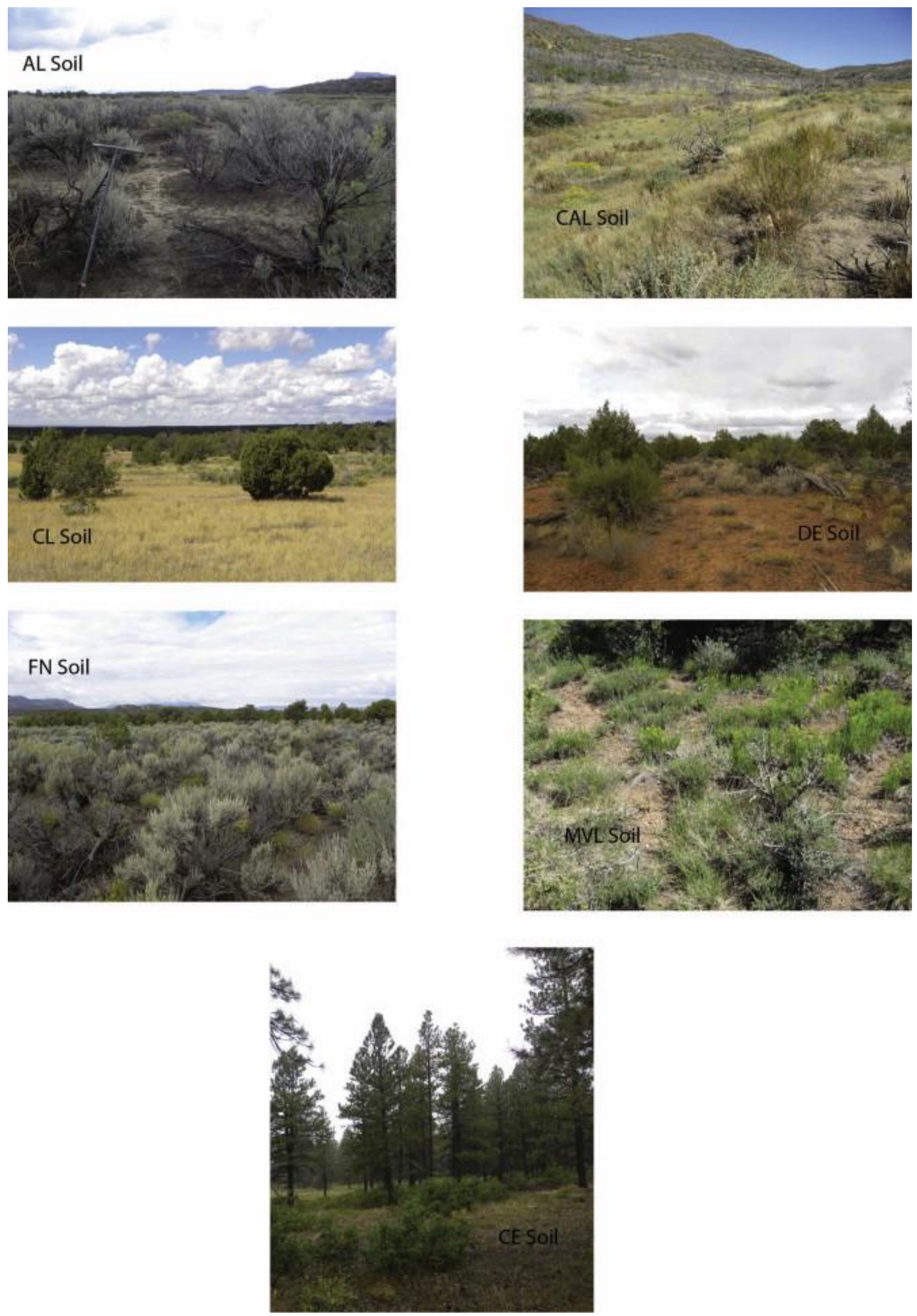
Supplementary Fig. 3.

Vegetation covering seven southwestern Colorado soil groups suitable for prehistoric agriculture. AL, CAL, CL, DE, FN, MVL, and CE stand, respectively for alluvial, Mesa Verde alluvial, clay, deep eolian, alluvial fan, Mesa Verde eolian, and cool eolian soils. 
Supplementary Table 1. Reconstructed water-year precipitation for Mesa Verde

\begin{tabular}{|c|c|c|c|c|c|c|c|c|c|c|}
\hline \multirow[b]{2}{*}{ Year (AD) } & \multicolumn{10}{|c|}{ precipitation $(\mathrm{cm})$} \\
\hline & 1 & 2 & 3 & 4 & 5 & 6 & 7 & 8 & 9 & 10 \\
\hline 60 & 39.4 & 36.3 & 37.4 & 39.5 & 64.1 & 43.1 & 43.7 & 73.2 & 34.3 & 42.4 \\
\hline 61 & 24.9 & 54.8 & 38.5 & 37.3 & 37.7 & 40.5 & 47.3 & 59.7 & 41.7 & 19.9 \\
\hline 62 & 87.4 & 51.9 & 52.5 & 53.4 & 41.6 & 41.8 & 50.7 & 51.0 & 49.3 & 42.6 \\
\hline 63 & 51.9 & 39.9 & 32.6 & 32.3 & 47.0 & 74.4 & 42.1 & 47.1 & 33.1 & 41.0 \\
\hline 64 & 43.9 & 47.7 & 39.0 & 37.9 & 32.3 & 34.4 & 42.9 & 43.7 & 54.1 & 36.9 \\
\hline 65 & 43.1 & 43.6 & 43.8 & 45.2 & 44.5 & 51.0 & 46.4 & 45.1 & 52.6 & 32.8 \\
\hline 66 & 37.4 & 47.1 & 32.6 & 33.8 & 48.3 & 51.5 & 51.4 & 50.4 & 48.4 & 56.5 \\
\hline 67 & 43.3 & 62.9 & 56.4 & 66.8 & 59.7 & 56.3 & 48.3 & 45.9 & 54.6 & 53.6 \\
\hline 68 & 49.8 & 57.5 & 54.5 & 48.6 & 57.1 & 43.9 & 56.5 & 51.9 & 61.7 & 54.5 \\
\hline 69 & 69.1 & 43.8 & 65.5 & 54.2 & 61.2 & 56.6 & 37.1 & 64.6 & 50.7 & 58.9 \\
\hline 70 & 50.7 & 47.3 & 43.0 & 25.6 & 45.1 & 23.2 & 26.3 & 42.0 & 29.4 & 47.6 \\
\hline 71 & 41.0 & 44.8 & 47.0 & 43.1 & 46.7 & 39.5 & 22.6 & 40.9 & 51.5 & 54.8 \\
\hline 72 & 36.4 & 44.2 & 42.2 & 24.5 & 66.0 & 53.2 & 55.9 & 49.9 & 50.9 & 61.2 \\
\hline 73 & 54.5 & 51.5 & 65.9 & 32.9 & 52.3 & 51.6 & 59.3 & 13.9 & 46.4 & 49.2 \\
\hline 74 & 46.8 & 30.7 & 54.2 & 49.2 & 39.8 & 49.2 & 54.1 & 38.2 & 53.1 & 38.3 \\
\hline 75 & 21.3 & 45.0 & 50.6 & 40.2 & 46.3 & 43.5 & 36.0 & 58.0 & 52.2 & 41.0 \\
\hline 76 & 57.8 & 47.2 & 44.9 & 40.4 & 63.1 & 51.0 & 37.0 & 54.0 & 46.6 & 34.1 \\
\hline 77 & 42.3 & 55.3 & 44.3 & 27.5 & 43.4 & 48.4 & 46.1 & 17.7 & 31.1 & 57.4 \\
\hline 78 & 46.5 & 51.0 & 47.2 & 60.4 & 55.6 & 40.8 & 66.1 & 34.5 & 54.9 & 55.5 \\
\hline 79 & 50.8 & 50.2 & 53.0 & 62.9 & 27.5 & 65.7 & 23.8 & 58.4 & 48.8 & 58.2 \\
\hline 80 & 32.7 & 71.2 & 67.2 & 53.6 & 52.3 & 46.4 & 49.2 & 35.1 & 20.3 & 68.3 \\
\hline 81 & 42.6 & 40.9 & 43.7 & 60.4 & 51.6 & 45.6 & 34.5 & 49.4 & 29.9 & 60.5 \\
\hline 82 & 63.5 & 55.7 & 26.1 & 55.1 & 37.2 & 53.3 & 35.4 & 61.2 & 26.6 & 34.0 \\
\hline 83 & 48.3 & 55.4 & 48.2 & 40.2 & 34.3 & 52.6 & 38.1 & 55.6 & 40.9 & 28.8 \\
\hline 84 & 46.1 & 33.4 & 56.5 & 34.3 & 55.6 & 46.2 & 25.7 & 57.2 & 44.3 & 49.4 \\
\hline 85 & 39.7 & 67.3 & 52.7 & 62.1 & 50.3 & 61.5 & 27.6 & 59.1 & 32.5 & 53.7 \\
\hline 86 & 50.6 & 63.0 & 25.1 & 63.4 & 49.4 & 40.1 & 30.6 & 39.0 & 66.6 & 36.1 \\
\hline 87 & 55.7 & 43.5 & 51.4 & 45.6 & 46.1 & 59.6 & 28.8 & 35.8 & 47.8 & 31.9 \\
\hline 88 & 50.7 & 42.7 & 34.3 & 27.6 & 49.6 & 44.8 & 47.5 & 47.0 & 48.4 & 57.0 \\
\hline 89 & 42.8 & 33.2 & 52.0 & 30.1 & 34.8 & 67.1 & 53.6 & 51.1 & 72.8 & 58.3 \\
\hline 90 & 26.7 & 59.9 & 32.7 & 39.2 & 55.3 & 20.4 & 27.1 & 52.3 & 53.3 & 54.2 \\
\hline 91 & 62.8 & 57.5 & 55.5 & 59.0 & 50.5 & 40.1 & 57.2 & 49.5 & 58.0 & 41.1 \\
\hline 92 & 54.6 & 28.6 & 28.5 & 32.7 & 44.5 & 46.5 & 40.1 & 49.9 & 55.3 & 31.1 \\
\hline 93 & 51.2 & 45.9 & 42.6 & 46.7 & 45.4 & 47.4 & 31.2 & 50.6 & 34.0 & 42.8 \\
\hline 94 & 49.6 & 48.8 & 44.1 & 48.5 & 47.8 & 56.6 & 53.7 & 56.9 & 53.0 & 52.1 \\
\hline 95 & 42.1 & 58.3 & 32.7 & 36.8 & 33.5 & 62.5 & 28.1 & 36.7 & 45.5 & 59.7 \\
\hline 96 & 37.8 & 60.4 & 47.6 & 51.6 & 34.4 & 66.5 & 48.9 & 40.8 & 36.1 & 50.1 \\
\hline 97 & 54.1 & 20.5 & 81.5 & 62.0 & 36.1 & 42.7 & 63.0 & 34.1 & 46.1 & 19.5 \\
\hline 98 & 26.8 & 56.3 & 29.4 & 38.5 & 49.3 & 45.2 & 72.7 & 73.7 & 80.6 & 46.0 \\
\hline 99 & 25.3 & 48.9 & 41.0 & 48.3 & 45.3 & 54.1 & 42.8 & 49.0 & 42.0 & 49.8 \\
\hline 100 & 34.0 & 36.1 & 49.2 & 43.7 & 20.5 & 58.9 & 56.4 & 55.8 & 25.2 & 46.4 \\
\hline 101 & 49.0 & 47.0 & 36.1 & 48.5 & 56.2 & 52.1 & 59.2 & 35.9 & 24.0 & 60.3 \\
\hline 102 & 51.4 & 46.2 & 52.4 & 58.7 & 55.1 & 46.3 & 50.7 & 49.6 & 48.2 & 31.2 \\
\hline 103 & 46.8 & 30.9 & 35.2 & 50.1 & 28.9 & 35.0 & 53.6 & 38.6 & 44.9 & 45.7 \\
\hline 104 & 29.3 & 55.6 & 40.6 & 34.3 & 43.6 & 30.3 & 52.4 & 30.7 & 55.8 & 48.3 \\
\hline 105 & 38.6 & 54.9 & 39.0 & 53.8 & 29.8 & 58.0 & 45.4 & 55.5 & 47.7 & 44.5 \\
\hline 106 & 54.8 & 29.3 & 81.6 & 66.3 & 76.2 & 50.6 & 34.2 & 32.3 & 51.6 & 46.5 \\
\hline 107 & 33.5 & 47.8 & 45.2 & 45.2 & 51.6 & 51.1 & 51.1 & 46.7 & 56.0 & 71.1 \\
\hline 108 & 33.2 & 42.6 & 41.5 & 53.9 & 24.4 & 44.1 & 57.3 & 53.3 & 49.1 & 21.9 \\
\hline 109 & 37.2 & 49.6 & 31.1 & 41.7 & 42.5 & 44.7 & 36.7 & 41.3 & 31.1 & 47.5 \\
\hline
\end{tabular}




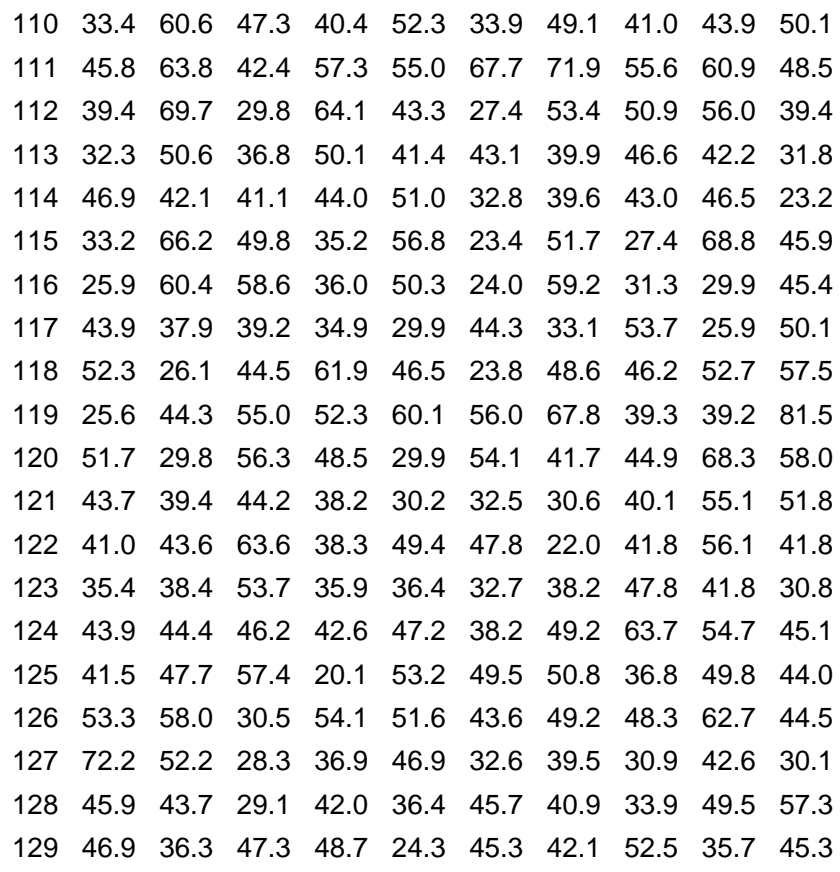


Unit Map Unit Name

1 Ackmen loam, 1 to 3 percent slopes

2 Ackmen loam, 3 to 6 percent slopes

3 Arabrab loamy sand, 3 to 9 percent slope

4 Arabrab-Longburn complex, 3 to 15 percent slope

5 Archuleta-Sanchez complex, 12 to 65 percent slopes

6 Argiustolls-Haplustalfs complex, 30 to 80 percent slopes

7 Argiustolls-Haplustalfs-Rock outcrop complex, 30 to 80 percent slopes

8 Barx loam, 3 to 6 percent slopes

Barx loam, 6 to 12 percent slopes

4 percent slopes

11 Barx-Gapmesa complex, 2 to 6 percent slopes

12 Battlerock clay loam, 0 to 6 percent slopes

13 Beje-Tragmon complex, 3 to 9 percent slopes

14 Burnson loam, 1 to 15 percent slopes

15 Burnson loam, dry, 1 to 15 percent slopes

16 Burnson-Herm complex, 15 to 30 percent slopes

17 Cahona loam, 1 to 3 percent slope

18 Cahona loam, 3 to 6 percent slopes

19 Cahona loam, 6 to 12 percent slopes

20 Cahona-Pulpit complex, 3 to 9 percent slopes

21 Cahona-Sharps-Wetherill complex, 2 to 6 percent slopes

22 Claysprings very stony clay loam, 12 to 65 percent slopes

23 Collide clay loam, 3 to 6 percent slopes

24 Collide clay loam, 6 to 12 percent slopes

25 Collide complex, 0 to 2 percent slopes

26 Collide complex, 2 to 6 percent slopes

27 Dalmatian-Apmay-Schrader complex, 0 to 5 percent slopes

28 Dam

29 Endoaquolls-Ustifluvents complex, 0 to 5 percent slopes

30 Falconry gravelly fine sandy loam, 3 to 25 percent slopes

31 Farb-Rock outcrop complex, 3 to 12 percent slopes

32 Fardraw loam, 3 to 15 percent slopes

33 Fardraw very cobbly loam, 0 to 9 percent slopes

34 Fardraw very cobbly loam, 9 to 25 percent slope

35 Fardraw-Granath complex, 3 to 12 percent slopes

36 Fivepine-Nortez complex, 0 to 15 percent slopes

37 Fluvaquents-Haplustolls complex, 0 to 5 percent slopes

38 Fluvents-Fluvaquents complex, 0 to 3 percent slopes

39 Fughes loam, 1 to 12 percent slope

40 Fughes-Herm complex, 5 to 25 percent slopes
Map Unit Type Code Unit Map Unit Name

Consociation

AL 1 Ackmen loam, 1 to 3 percent slopes

Consociation SH 27 Dalmatian-Apmay-Schrader complex, 0 to 5 percent slopes

Complex $\quad$ SH 29 Endoaquolls-Ustifluvents complex, 0 to 5 percent slopes

Complex ST 37 Fluvaquents-Haplustolls complex, 0 to 5 percent slopes

Complex ST 12 Battlerock clay loam, 0 to 6 percent slopes

Complex ST 38 Fluvents-Fluvaquents complex, 0 to 3 percent slopes

Consociation DE 62 Irak loam, 0 to 3 percent slopes

Consociation DE 65 Lillings silt loam, sodic, 1 to 3 percent slopes

Consociation DE 66 Lillings silty clay loam, 1 to 3 percent slopes

Complex

Consociation

Complex

Consociation

Consociation

Complex

Consociation

Consociation

Consociation

Complex

Complex

Consociation

Consociation

Consociation

Complex

Complex

Complex

Consociation

Complex

Consociation

Complex

Consociation

Consociation

Consociation

Complex

Complex

Complex

Consociation

Complex
67 Lillings silty clay loam, 3 to 6 percent slopes

84 Payter sandy loam, 3 to 15 percent slopes

88 Pogo loam, 0 to 2 percent slopes

96 Purcella loam, 0 to 3 percent slopes

97 Ramper clay loam, 0 to 3 percent slopes

98 Ramper loam, 0 to 3 percent slopes

99 Ravola clay loam, 0 to 3 percent slope

134 Umbarg-Winner-Tesajo complex, 0 to 2 percent slopes

136 Ustic Torriorthents-Gullied land complex, 1 to 60 percent slopes

55 Hesperus sandy loam, 3 to 12 percent slopes

132 Typic Argiaquolls, 0 to 3 percent slopes

13 Beje-Tragmon complex, 3 to 9 percent slopes

14 Burnson loam, 1 to 15 percent slopes

15 Burnson loam, dry, 1 to 15 percent slopes

16 Burnson-Herm complex, 15 to 30 percent slopes

32 Fardraw loam, 3 to 15 percent slopes

33 Fardraw very cobbly loam, 0 to 9 percent slopes

34 Fardraw very cobbly loam, 9 to 25 percent slopes
Consociation

Complex

Complex

Complex

Consociation

Complex

Consociation

Consociation

Consociation

Consociation

Consociation

Consociation

Consociation

Consociation

Consociation

Consociation

Complex

Complex

Consociation

Consociation

Complex

Consociation

Consociation

Complex

Consociation

Consociation

Consociation

Complex

Complex

Consociation

Complex

Complex

Consociation

Consociation

Consociation

Complex

Complex

Complex

Consociation
35 Fardraw-Granath complex, 3 to 12 percent slopes

mplex, 0 to 15 percent slopes

39 Fughes loam, 1 to 12 percent slopes

40 Fughes-Herm complex, 5 to 25 percent slopes

41 Fughes-Sheek complex, 15 to 30 percent slopes

43 Goldbug very stony fine sandy loam, 5 to 30 percent slopes

44 Granath loam, 3 to 6 percent slopes

45 Granath loam, 6 to 12 percent slopes

46 Granath-Fughes complex, 0 to 15 percent slopes

47 Granath-Nortez complex, 0 to 15 percent slopes

48 Granath-Ormiston-Fivepine complex, 0 to 15 percent slopes

CE 49 Herm loam, 6 to 25 percent slopes

CE

CE 
45 Granath loam, 6 to 12 percent slopes

46 Granath-Fughes complex, 0 to 15 percent slopes

47 Granath-Nortez complex, 0 to 15 percent slopes

48 Granath-Ormiston-Fivepine complex, 0 to 15 percent slopes

49 Herm loam, 6 to 25 percent slopes

50 Herm very cobbly loam, 15 to 40 percent slopes

51 Herm-Pagoda complex, 0 to 15 percent slopes

52 Hesperus loam, 0 to 3 percent slopes

53 Hesperus loam, 3 to 6 percent slopes

54 Hesperus loam, 6 to 12 percent slopes

55 Hesperus sandy loam, 3 to 12 percent slopes

56 llex loam, 3 to 12 percent slopes

57 llex loam, 12 to 25 percent slopes

58 llex-Granath complex, 2 to 6 percent slopes

59 llex-Granath complex, 6 to 12 percent slopes

60 Ilex-Pramiss-Falconry complex, 3 to 20 percent slopes

61 llex-Pramiss-Granath complex, 2 to 9 percent slope

62 Irak loam, 0 to 3 percent slopes

63 Jemco-Detra-Beje complex, 1 to 15 percent slopes

64 Lazear-Rock outcrop complex, 12 to 65 percent slopes

65 Lillings silt loam, sodic, 1 to 3 percent slopes

66 Lillings silty clay loam, 1 to 3 percent slopes

67 Lillings silty clay loam, 3 to 6 percent slopes

68 Longburn-Rock outcrop complex, 10 to 45 percent slopes

69 Longburn-Rock outcrop complex, 45 to 80 percent slopes

70 Mack fine sandy loam, 0 to 6 percent slopes

71 Mikett clay loam, saline-sodic, 0 to 3 percent slopes

72 Mikett clay loam, 0 to 3 percent slopes

73 Mikim clay loam, 1 to 3 percent slopes

74 Mikim clay loam, sodic, 0 to 3 percent slopes

75 Mikim loam, 3 to 6 percent slopes

76 Morefield loam, 1 to 3 percent slopes

77 Morefield loam, 3 to 6 percent slopes

78 Nortez-Granath complex, 0 to 6 percent slopes

79 Northrim cobbly loam, 15 to 40 percent slopes

80 Ormiston-Beje complex, 5 to 30 percent slopes

81 Ormiston-Fivepine complex, 0 to 15 percent slopes

82 Ormiston-Granath

83 Ormiston-Nortez complex, 3 to 12 percent slope

Consociation

Consociatio

Consociation

Complex

Complex

Complex

Consociatio

Consociation

Complex

Consociation

Consociation

Consociatio

Consociation

Consociation

Consociation

Complex

Complex

Complex

Complex

Consociation

Complex

Complex

Consociation

Consociation

Consociation

Complex

Complex

Consociation

Consociation

Consociation

Consociation

Consociation

Consociation

Consociation

Complex

Consociation

Complex

Complex

Complex

Complex

51 Herm-Pagoda complex, 0 to 15 percent slopes

52 Hesperus loam, 0 to 3 percent slopes

53 Hesperus loam, 3 to 6 percent slopes

54 Hesperus loam, 6 to 12 percent slopes

56 Ilex loam, 3 to 12 percent slopes

57 llex loam, 12 to 25 percent slopes

58 llex-Granath complex, 2 to 6 percent slopes

59 llex-Granath complex, 6 to 12 percent slopes

60 Ilex-Pramiss-Falconry complex, 3 to 20 percent slopes

61 llex-Pramiss-Granath complex, 2 to 9 percent slopes

63 Jemco-Detra-Beje complex, 1 to 15 percent slopes

81 Ormiston-Fivepine complex, 0 to 15 percent slopes

82 Ormiston-Granath complex, 1 to 12 percent slopes

83 Ormiston-Nortez complex, 3 to 12 percent slopes

90 Pramiss-Granath complex, 3 to 9 percent slopes

102 Ricot loam, 1 to 3 percent slopes

103 Ricot loam, 3 to 6 percent slopes

104 Ricot loam, 6 to 12 percent slopes

123 Sideshow silty clay loam, 0 to 3 percent slopes

124 Sideshow silty clay loam, 3 to 6 percent slopes

125 Sideshow silty clay loam, 6 to 12 percent slopes

126 Sideshow-Zigzag complex, 3 to 25 percent slopes

127 Sideslide silty clay loam, 3 to 9 percent slopes

8 Barx loam, 3 to 6 percent slopes

9 Barx loam, 6 to 12 percent slopes

10 Barx very fine sandy loam, 1 to 4 percent slopes

11 Barx-Gapmesa complex, 2 to 6 percent slope

17 Cahona loam, 1 to 3 percent slopes

18 Cahona loam, 3 to 6 percent slopes

19 Cahona loam, 6 to 12 percent slopes

20 Cahona-Pulpit complex, 3 to 9 percent slopes

21 Cahona-Sharps-Wetherill complex, 2 to 6 percent slopes

23 Collide clay loam, 3 to 6 percent slopes

FN 24 Collide clay loam, 6 to 12 percent slopes

MVL 25 Collide complex, 0 to 2 percent slopes

MVL 26 Collide complex, 2 to 6 percent slopes

DE 78 Nortez-Granath complex, 0 to 6 percent slopes

85 Pinacol loam, 1 to 12 percent slopes

93 Pulpit loam, 3 to 12 percent slopes

94 Pulpit loam, 3 to 6 percent slopes

95 Pulpit loam, 6 to 12 percent slopes

112 Sharps loam, 3 to 6 percent slopes

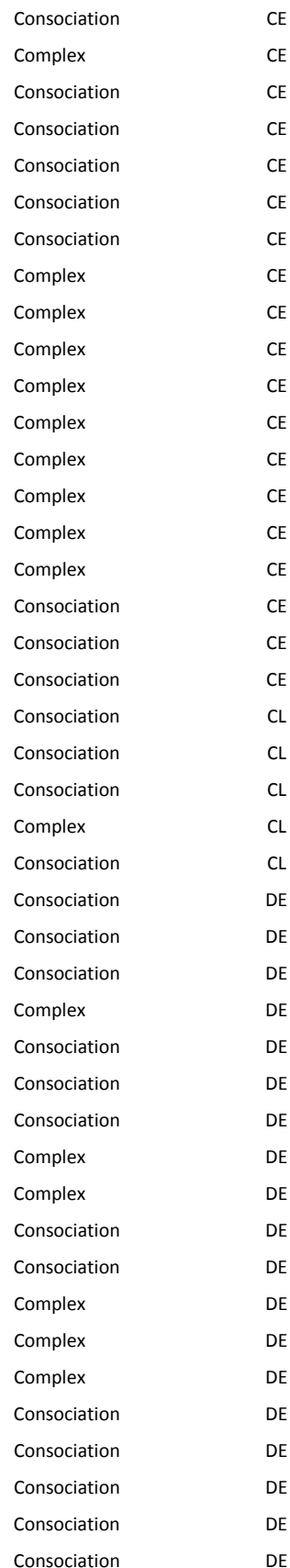


84 Payter sandy loam, 3 to 15 percent slopes

85 Pinacol loam, 1 to 12 percent slopes

86 Pinacol loam, 12 to 40 percent slopes

87 Pits

88 Pogo loam, 0 to 2 percent slopes

89 Pramiss very cobbly loam, 6 to 25 percent slopes

90 Pramiss-Granath complex, 3 to 9 percent slopes

91 Prater loam, 10 to 25 percent slopes

92 Prater-Dolcan complex, 25 to 60 percent slopes

93 Pulpit loam, 3 to 12 percent slopes

94 Pulpit loam, 3 to 6 percent slopes

95 Pulpit loam, 6 to 12 percent slopes

96 Purcella loam, 0 to 3 percent slopes

97 Ramper clay loam, 0 to 3 percent slopes

98 Ramper loam, 0 to 3 percent slopes

99 Ravola clay loam, 0 to 3 percent slopes

100 Recapture fine sandy loam, 0 to 6 percent slopes

101 Recapture sandy loam, 0 to 6 percent slopes

102 Ricot loam, 1 to 3 percent slopes

103 Ricot loam, 3 to 6 percent slopes

104 Ricot loam, 6 to 12 percent slopes

105 Rizno-Gapmesa complex, 3 to 9 percent slopes

106 Rizno-Littlenan-Bodry association, 3 to 50 percent slopes

107 Rizno-Ruinpoint-Rock outcrop complex, 1 to 15 percent slopes

108 Rock outcrop

109 Romberg-Crosscan complex, 6 to 25 percent slopes

110 Romberg-Crosscan-Rock outcrop complex, 25 to 80 percent slopes

111 Roubideau loam, 1 to 6 percent slope

112 Sharps loam, 3 to 6 percent slopes

113 Sharps loam, 6 to 12 percent slopes

114 Sharps loam, dry, 6 to 12 percent slopes

115 Sharps, dry-Gapmesa complex, 6 to 12 percent slopes

116 Sharps-Cahona complex, 6 to 12 percent slopes

117 Sharps-Pulpit complex, 2 to 6 percent slopes

118 Sharps-Pulpit complex, 6 to 12 percent slope

119 Sheek-Archuleta complex, 6 to 25 percent slopes

120 Sheek-Archuleta-Rock outcrop complex, 25 to 80 percent slopes

121 Sheek-Archuleta-Rock outcrop complex, 25 to 80 percent slopes, north aspect

122 Sheppard fine sand, 1 to 6 percent slopes

123 Sideshow silty clay loam, 0 to 3 percent slopes

124 Sideshow silty clay loam, 3 to 6 percent slopes

125 Sideshow silty clay

126 Sideshow-Zigzag complex, 3 to 25 percent slopes
Consociation

Complex

Consociation

Complex

Consociation

Consociation

Consociation

Consociation

Consociatio

Consociation

Consociation

Consociation

Consociation

Consociation

Consociation

Consociatio

Complex

Association

Complex

Consociation

Complex

Complex

Consociatio

Consociation

Consociation

Consociation

Complex

Complex

Complex

Complex

Complex

Complex

Consociation

Consociation

Consociation

Consociation

Complex

75 Mikim loam, 3 to 6 percent slopes
115 Sharps, dry-Gapmesa complex, 6 to 12 percent slopes

116 Sharps-Cahona complex, 6 to 12 percent slopes

117 Sharps-Pulpit complex, 2 to 6 percent slopes

118 Sharps-Pulpit complex, 6 to 12 percent slopes

143 Wetherill loam, 1 to 3 percent slopes

144 Wetherill loam, 3 to 6 percent slopes

145 Wetherill loam, 6 to 12 percent slopes

71 Mikett clay loam, saline-sodic, 0 to 3 percent slopes

72 Mikett clay loam, 0 to 3 percent slopes

73 Mikim clay loam, 1 to 3 percent slopes

74 Mikim clay loam, sodic, 0 to 3 percent slopes

135 Ustic Torrifluvents, 0 to 3 percent slopes

146 Yarts clay loam, 1 to 6 percent slopes

147 Yarts fine sandy loam, 1 to 6 percent slopes

76 Morefield loam, 1 to 3 percent slopes

77 Morefield loam, 3 to 6 percent slopes

111 Roubideau loam, 1 to 6 percent slopes

3 Arabrab loamy sand, 3 to 9 percent slopes

4 Arabrab-Longburn complex, 3 to 15 percent slopes

30 Falconry gravelly fine sandy loam, 3 to 25 percent slopes

31 Farb-Rock outcrop complex, 3 to 12 percent slopes

42 Gladel-Pulpit complex, 3 to 9 percent slopes

64 Lazear-Rock outcrop complex, 12 to 65 percent slopes

68 Longburn-Rock outcrop complex, 10 to 45 percent slopes

69 Longburn-Rock outcrop complex, 45 to 80 percent slope

128 Stephouse-Rock outcrop complex, 3 to 10 percent slopes

149 Zigzag very channery clay loam, 3 to 25 percent slopes

150 Zigzag-Sideshow complex, 25 to 65 percent slopes

151 Zyme gravelly clay loam, 3 to 12 percent slopes

152 Zyme very channery clay loam, 12 to 65 percent slopes

5 Archuleta-Sanchez complex, 12 to 65 percent slopes

6 Argiustolls-Haplustalfs complex, 30 to 80 percent slopes

7 Argiustolls-Haplustalfs-Rock outcrop complex, 30 to 80 percent slopes

79 Northrim cobbly loam, 15 to 40 percent slopes

80 Ormiston-Beje complex, 5 to 30 percent slopes

86 Pinacol loam, 12 to 40 percent slopes

89 Pramiss very cobbly loam, 6 to 25 percent slopes

91 Prater loam, 10 to 25 percent slopes

CL 92 Prater-Dolcan complex, 25 to 60 percent slopes

CL 109 Romberg-Crosscan complex, 6 to 25 percent slopes

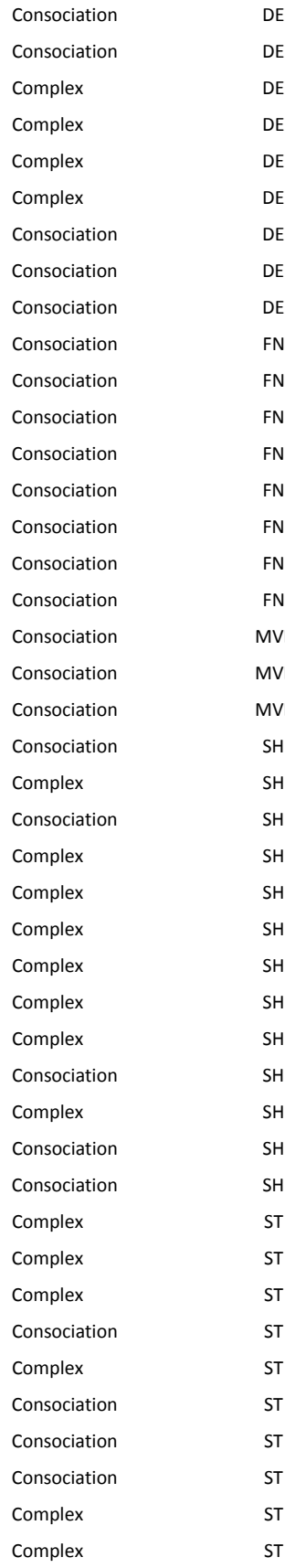


127 Sideslide silty clay loam, 3 to 9 percent slopes

128 Stephouse-Rock outcrop complex, 3 to 10 percent slopes 129 Torriorthents, 12 to 65 percent slopes

130 Torriorthents-Badland complex, 25 to 100 percent slopes

131 Tragmon-Sheek complex, 12 to 25 percent slopes

132 Typic Argiaquolls, 0 to 3 percent slopes

133 Typic Torriorthents-Rock outcrop complex, 12 to 80 percent slopes

134 Umbarg-Winner-Tesajo complex, 0 to 2 percent slopes

135 Ustic Torrifluvents, 0 to 3 percent slopes

136 Ustic Torriorthents-Gullied land complex, 1 to 60 percent slopes

137 Ustorthents, 12 to 65 percent slopes

138 Uzacol-Zwicker-Claysprings complex, 3 to 12 percent slopes

139 Water

140 Wauquie very stony loam, 6 to 25 percent slopes

141 Wauquie-Dolcan complex, 6 to 25 percent slope

142 Wauquie-Dolcan-Rock outcrop complex, 25 to 80 percent slopes

143 Wetherill loam, 1 to 3 percent slopes

144 Wetherill loam, 3 to 6 percent slopes

145 Wetherill loam, 6 to 12 percent slopes

146 Yarts clay loam, 1 to 6 percent slopes

147 Yarts fine sandy loam, 1 to 6 percent slopes

148 Zau stony loam, 9 to 25 percent slopes

149 Zigzag very channery clay loam, 3 to 25 percent slopes

150 Zigzag-Sideshow complex, 25 to 65 percent slopes

151 Zyme gravelly clay loam, 3 to 12 percent slopes

152 Zyme very channery clay loam, 12 to 65 percent slopes
Consociation

Complex

Consociation

Complex

Complex

Consociation

Complex

Complex

Consociation

Complex

Consociation

Complex

Undiff

Consociation

Complex

Complex

Consociation

Consociation

Consociation

Consociation

Consociation

Consociation

Consociation

Complex

Consociation

Consociation
110 Romberg-Crosscan-Rock outcrop complex, 25 to 80 percent slopes

SH 119 Sheek-Archuleta complex, 6 to 25 percent slopes

120 Sheek-Archuleta-Rock outcrop complex, 25 to 80 percent slopes

121 Sheek-Archuleta-Rock outcrop complex, 25 to 80 percent slopes, north aspect

ST 131 Tragmon-Sheek complex, 12 to 25 percent slopes

AL 133 Typic Torriorthents-Rock outcrop complex, 12 to 80 percent slopes

137 Ustorthents, 12 to 65 percent slopes

140 Wauquie very stony loam, 6 to 25 percent slopes

141 Wauquie-Dolcan complex, 6 to 25 percent slopes

142 Wauquie-Dolcan-Rock outcrop complex, 25 to 80 percent slopes

148 Zau stony loam, 9 to 25 percent slopes

DR 22 Claysprings very stony clay loam, 12 to 65 percent slopes

MC 106 Rizno-Littlenan-Bodry association, 3 to 50 percent slopes

138 Uzacol-Zwicker-Claysprings complex, 3 to 12 percent slopes

70 Mack fine sandy loam, 0 to 6 percent slopes

100 Recapture fine sandy loam, 0 to 6 percent slopes

101 Recapture sandy loam, 0 to 6 percent slopes

105 Rizno-Gapmesa complex, 3 to 9 percent slopes

107 Rizno-Ruinpoint-Rock outcrop complex, 1 to 15 percent slopes

122 Sheppard fine sand, 1 to 6 percent slopes

FN 28 Dam

87 Pits

SH 108 Rock outcrop

SH 129 Torriorthents, 12 to 65 percent slopes

$\mathrm{SH} \quad 130$ Torriorthents-Badland complex, 25 to 100 percent slopes

SH 139 Water

$\begin{array}{ll}\text { Complex } & \text { ST } \\ \text { Complex } & \text { ST } \\ \text { Complex } & \text { ST } \\ \text { Complex } & \text { ST } \\ \text { Complex } & \text { ST } \\ \text { Complex } & \text { ST } \\ \text { Consociation } & \text { ST } \\ \text { Consociation } & \text { ST } \\ \text { Complex } & \text { ST } \\ \text { Complex } & \text { ST } \\ \text { Consociation } & \text { ST } \\ \text { Consociation } & \text { DR } \\ \text { Association } & \text { DR } \\ \text { Complex } & \text { DR } \\ \text { Consociation } & \text { ED } \\ \text { Consociation } & \text { ED } \\ \text { Consociation } & \text { ED } \\ \text { Complex } & \text { ED } \\ \text { Complex } & \text { ED } \\ \text { Consociation } & \text { ED } \\ \text { Consociation } & \text { MC } \\ \text { Consociation } & \text { MC } \\ \text { Consociation } & \text { MC } \\ \text { Consociation } & \text { MC } \\ \text { Complex } & \text { MC } \\ \text { Undifferentiated group } & \text { MC }\end{array}$


Supplementary Table 3. Elevations, locations and total $\mathrm{N}$ values in top $50 \mathrm{~cm}$ of study area soils

Sample No. Ele

(m)

Cool eolian soils (loess) (9/14/2011)

CE-1 $2390 \quad 12 S$

CE-2 $2391 \quad 12 S$

CE-4 $2384 \quad 12 S$

CE-5 $2382 \quad 12 S$

CE-6 $2382 \quad 12 S$

CE-7 $2328-12 S$

CE-8 $2330 \quad 12 S$

CE-9 $2335 \quad 12 S$

CE-10 $2336 \quad 12 S$

CE-11 $2339 \quad 12 S$

CE-12 $2344 \quad 12 S$

CE-13 $2322 \quad 12 S$

CE-14 $2319 \quad 12 S$

CE-15 $2321 \quad 12 S$

CE-16 $2318 \quad 12 S$

CE-17 $2317 \quad 12 S$

CE-18 $2320 \quad 12 S$

CE-19 $2306 \quad 12 S$

CE-20

CE-21

CE-22

CE-23

CE-24

CE-25

CE-26

CE-27

CE-28

CE-29

CE-30
CE-3 $2383 \quad 12 S$

UTM Cooridinates

Total N $(50 \mathrm{~cm})$

$(\% \mathrm{~N})$

$\begin{array}{lll}695146 & 4183781 & 0.097 \\ 695184 & 4183755 & 0.098 \\ 695186 & 4183727 & 0.147 \\ 695159 & 4183729 & 0.114 \\ 695141 & 4183718 & 0.101 \\ 695129 & 4183676 & 0.104\end{array}$

$\begin{array}{lll}695290 & 4182230 & 0.074\end{array}$

$\begin{array}{lll}695331 & 4182228 & 0.088\end{array}$

$\begin{array}{lll}695379 & 4182235 & 0.119\end{array}$

$\begin{array}{lll}695386 & 4182199 & 0.107\end{array}$

$\begin{array}{lll}695415 & 4182150 & 0.118\end{array}$

$\begin{array}{lll}695461 & 4182145 & 0.068\end{array}$

$\begin{array}{lll}694732 & 4181707 & 0.103\end{array}$

$\begin{array}{lll}694725 & 4181745 & 0.095\end{array}$

$\begin{array}{lll}694731 & 4181817 & 0.110\end{array}$

$\begin{array}{lll}694650 & 4181857 & 0.097\end{array}$

$\begin{array}{lll}694661 & 4181803 & 0.111\end{array}$

$\begin{array}{lll}694700 & 4181763 & 0.092\end{array}$

$\begin{array}{lll}694252 & 4181544 & 0.077\end{array}$

$\begin{array}{lll}694313 & 4181499 & 0.110\end{array}$

$\begin{array}{lll}694362 & 4181513 & 0.099\end{array}$

$\begin{array}{lll}694386 & 4181567 & 0.093\end{array}$

$\begin{array}{lll}694432 & 4181583 & 0.090\end{array}$

$\begin{array}{lll}694468 & 4181600 & 0.081\end{array}$

$\begin{array}{lll}693090 & 4181865 & 0.094\end{array}$

$\begin{array}{lll}693062 & 4181915 & 0.112\end{array}$

$\begin{array}{lll}693003 & 4181918 & 0.093\end{array}$

$\begin{array}{lll}692955 & 4181941 & 0.103\end{array}$

$\begin{array}{lll}692934 & 4181991 & 0.080\end{array}$

$\begin{array}{lll}693104 & 4181953 & 0.086\end{array}$

Deep eolian soils (loess) (9/14/2011)

DE-1

DE-2

$2064 \quad 12 S$

684388

4141946

0.076

694408

4141967

0.093

694437

4141989

0.108

694453

4141985

0.072

$\begin{array}{lll}694441 & 4141945 & 0.079\end{array}$

DE-5

$2064 \quad 12 S$ 


\begin{tabular}{|c|c|c|c|c|c|}
\hline DE-6 & 2060 & $12 S$ & 693971 & 4141889 & 0.082 \\
\hline DE-7 & 2063 & $12 S$ & 694010 & 4141873 & 0.056 \\
\hline DE-8 & 2065 & $12 S$ & 694013 & 4141843 & 0.053 \\
\hline DE-9 & 2063 & $12 S$ & 693989 & 4141818 & 0.039 \\
\hline DE-10 & 2066 & $12 S$ & 693964 & 4141838 & 0.027 \\
\hline DE-11 & 2044 & $12 S$ & 692540 & 4141777 & 0.037 \\
\hline DE-12 & 2045 & $12 S$ & 692539 & 4141810 & 0.035 \\
\hline DE-13 & 2045 & $12 S$ & 692530 & 4141847 & 0.035 \\
\hline DE-14 & 2045 & $12 S$ & 692541 & 4141898 & 0.053 \\
\hline DE-15 & 2043 & $12 S$ & 692488 & 4141879 & 0.052 \\
\hline DE-16 & 1959 & $12 S$ & 688104 & 4140844 & 0.065 \\
\hline DE-17 & 1959 & $12 S$ & 688132 & 4140865 & 0.028 \\
\hline DE-18 & 1958 & $12 S$ & 688167 & 4140892 & 0.044 \\
\hline DE-19 & 1959 & $12 S$ & 688214 & 4140889 & 0.040 \\
\hline DE-20 & 1959 & $12 S$ & 688270 & 4140891 & 0.022 \\
\hline DE-21 & 1975 & $12 S$ & 689176 & 4141078 & 0.036 \\
\hline DE-22 & 1975 & $12 S$ & 689216 & 4141089 & 0.053 \\
\hline DE-23 & 1977 & $12 S$ & 689249 & 4141099 & 0.053 \\
\hline DE-24 & 1977 & $12 S$ & 689286 & 4141097 & 0.066 \\
\hline DE-25 & 1980 & $12 \mathrm{~S}$ & 689313 & 4141070 & 0.038 \\
\hline \multicolumn{6}{|c|}{ Alluvial soils (9/15/2011) } \\
\hline AL-1 & 1939 & $12 S$ & 721913 & 4136569 & 0.049 \\
\hline AL-2 & 1939 & $12 S$ & 721946 & 4136575 & 0.036 \\
\hline AL-3 & 1941 & $12 S$ & 721978 & 4136623 & 0.037 \\
\hline AL-4 & 1940 & $12 S$ & 722041 & 4136661 & 0.057 \\
\hline AL-5 & 1941 & $12 S$ & 722100 & 4136699 & 0.045 \\
\hline AL-6 & 1938 & $12 S$ & 722168 & 4136663 & 0.080 \\
\hline AL-7 & 1937 & $12 S$ & 722239 & 4136646 & 0.066 \\
\hline AL-8 & 1935 & $12 S$ & 722315 & 4136665 & 0.095 \\
\hline AL-9 & 1935 & $12 S$ & 722347 & 4136739 & 0.055 \\
\hline AL-10 & 1936 & $12 S$ & 722384 & 4136826 & 0.048 \\
\hline AL-11 & 1936 & $12 S$ & 722432 & 4136883 & 0.040 \\
\hline AL-12 & 1937 & $12 S$ & 722477 & 4136951 & 0.057 \\
\hline AL-13 & 1936 & $12 S$ & 722510 & 4136995 & 0.056 \\
\hline AL-14 & 1935 & $12 S$ & 722479 & 4137059 & 0.108 \\
\hline AL-15 & 1936 & $12 S$ & 722469 & 4137123 & 0.151 \\
\hline AL-16 & 1934 & $12 S$ & 722604 & 4136801 & 0.089 \\
\hline AL-17 & 1935 & $12 S$ & 722566 & 4136748 & 0.064 \\
\hline AL-18 & 1934 & $12 S$ & 722530 & 4136655 & 0.085 \\
\hline AL-19 & 1933 & $12 S$ & 722534 & 4136586 & 0.071 \\
\hline
\end{tabular}




$\begin{array}{llllll}\text { AL-20 } & 1936 & 12 S & 722607 & 4136593 & 0.098 \\ \text { AL-21 } & & & & & \\ \text { AL-22 } & 1940 & 12 S & 722873 & 4136627 & 0.083 \\ \text { AL-23 } & 1941 & 12 S & 722927 & 4136563 & 0.112 \\ \text { AL-24 } & 1942 & 12 S & 722988 & 4136537 & 0.092 \\ \text { AL-25 } & 1944 & 12 S & 723050 & 4136519 & 0.079 \\ & 1938 & 12 S & 723109 & 4136517 & 0.094\end{array}$

Clay soils (derived from Mancos Shale) (9/15/2011)

\begin{tabular}{|c|c|c|c|c|c|}
\hline CL-1 & 2032 & $12 S$ & 727941 & 4137390 & 0.068 \\
\hline CL-2 & 2035 & $12 S$ & 727990 & 4137447 & 0.078 \\
\hline CL-3 & 2036 & $12 S$ & 728043 & 4137498 & 0.080 \\
\hline CL-4 & 2039 & $12 S$ & 728115 & 4137479 & 0.079 \\
\hline CL-5 & 2042 & $12 \mathrm{~S}$ & 728177 & 4137447 & 0.074 \\
\hline CL-6 & 2044 & $12 S$ & 728249 & 4137434 & 0.071 \\
\hline CL-7 & 2046 & $12 S$ & 728306 & 4137419 & 0.088 \\
\hline CL-8 & 2048 & $12 S$ & 728349 & 4137384 & 0.075 \\
\hline CL-9 & 2049 & $12 S$ & 728408 & 4137364 & 0.058 \\
\hline CL-10 & 2052 & $12 S$ & 728474 & 4137351 & 0.080 \\
\hline CL-11 & 2053 & $12 S$ & 728471 & 4137296 & 0.094 \\
\hline CL-12 & 2052 & $12 S$ & 728442 & 4137235 & 0.093 \\
\hline CL-13 & 2052 & $12 S$ & 728428 & 4137181 & 0.099 \\
\hline CL-14 & 2052 & $12 S$ & 728404 & 4137142 & 0.100 \\
\hline CL-15 & 2055 & $12 S$ & 728421 & 4137103 & 0.102 \\
\hline CL-16 & 2059 & $12 S$ & 728443 & 4137045 & 0.079 \\
\hline CL-17 & 2059 & $12 S$ & 728444 & 4136969 & 0.108 \\
\hline CL-18 & 2058 & $12 S$ & 728441 & 4136902 & 0.064 \\
\hline CL-19 & 2057 & $12 S$ & 728391 & 4136937 & 0.052 \\
\hline CL-20 & 2054 & $12 S$ & 728344 & 4136981 & 0.086 \\
\hline CL-21 & 2038 & $12 S$ & 727566 & 4137287 & 0.117 \\
\hline CL-22 & 2037 & $12 S$ & 727537 & 4137326 & 0.111 \\
\hline CL-23 & 2038 & $12 S$ & 727500 & 4137273 & 0.102 \\
\hline CL-24 & 2038 & $12 S$ & 727447 & 4137226 & 0.075 \\
\hline CL-25 & 2037 & $12 S$ & 727380 & 4137226 & 0.085 \\
\hline
\end{tabular}

Alluvial fan soils (9/16/2011)

$\begin{array}{llllll}\text { FN-1 } & 2032 & 12 S & 725493 & 4133115 & 0.152 \\ \text { FN-2 } & 2029 & 12 S & 725437 & 4133074 & 0.107 \\ \text { FN-3 } & 2027 & 12 S & 725371 & 4133011 & 0.132 \\ \text { FN-4 } & 2024 & 12 S & 725296 & 4132981 & 0.117 \\ \text { FN-5 } & 2020 & 12 S & 725192 & 4132880 & 0.108 \\ & & & & & \\ \text { FN-6 } & 2019 & 12 S & 725133 & 4132827 & 0.107\end{array}$




\begin{tabular}{|c|c|c|c|c|c|}
\hline $\mathrm{FN}-7$ & 2019 & $12 S$ & 725066 & 4132769 & 0.090 \\
\hline $\mathrm{FN}-8$ & 2019 & $12 S$ & 724965 & 4132685 & 0.104 \\
\hline FN-9 & 2018 & $12 S$ & 724895 & 4132654 & 0.104 \\
\hline FN-10 & 2019 & $12 S$ & 724820 & 4132563 & 0.098 \\
\hline FN-11 & 2021 & $12 S$ & 724761 & 4132505 & 0.096 \\
\hline FN-12 & 2021 & $12 S$ & 724716 & 4132460 & 0.131 \\
\hline FN-13 & 2019 & $12 S$ & 724662 & 4132404 & 0.087 \\
\hline FN-14 & 2022 & $12 S$ & 724607 & 4132350 & 0.084 \\
\hline FN-15 & 2023 & $12 S$ & 724556 & 4132294 & 0.172 \\
\hline FN-16 & 2026 & $12 S$ & 724597 & 4132229 & 0.106 \\
\hline FN-17 & 2026 & $12 S$ & 724649 & 4132250 & 0.098 \\
\hline FN-18 & 2027 & $12 S$ & 724705 & 4132271 & 0.111 \\
\hline FN-19 & 2028 & $12 S$ & 724754 & 4132296 & 0.093 \\
\hline $\mathrm{FN}-20$ & 2027 & $12 S$ & 724808 & 4132341 & 0.111 \\
\hline $\mathrm{FN}-21$ & 2027 & $12 S$ & 724852 & 4132366 & 0.112 \\
\hline $\mathrm{FN}-22$ & 2026 & $12 S$ & 724907 & 4132401 & 0.093 \\
\hline $\mathrm{FN}-23$ & 2027 & $12 S$ & 724959 & 4132420 & 0.081 \\
\hline $\mathrm{FN}-24$ & 2026 & $12 S$ & 724992 & 4132475 & 0.116 \\
\hline $\mathrm{FN}-25$ & 2022 & $12 S$ & 724955 & 4132525 & 0.115 \\
\hline \multicolumn{6}{|c|}{ Mesa Verde Chapin Mesa burned loessic soils (9/23/2008) } \\
\hline \multicolumn{6}{|c|}{ Elevation of Mesa Verde ranges between 2440 and $2560 \mathrm{~m}$} \\
\hline CMB1 & 2168 & $13 S$ & 190726 & 4122547 & 0.081 \\
\hline CMB2 & 2194 & $13 S$ & 190346 & 4123254 & 0.072 \\
\hline CMB3 & 2192 & $13 S$ & 190247 & 4123104 & 0.054 \\
\hline CMB4 & 2213 & $13 S$ & 190188 & 4123828 & 0.037 \\
\hline CMB5 & 2213 & $13 S$ & 190111 & 4123896 & 0.055 \\
\hline CMB6 & 2247 & $13 S$ & 189919 & 4124662 & 0.056 \\
\hline CMB7 & 2245 & $13 S$ & 189848 & 4124658 & 0.058 \\
\hline CMB8 & 2420 & $13 S$ & 189405 & 4128464 & 0.097 \\
\hline CMB9 & 2425 & $13 S$ & 189357 & 4128533 & 0.124 \\
\hline CMB10 & 2134 & $13 S$ & 191109 & 4121023 & 0.058 \\
\hline \multicolumn{6}{|c|}{ Mesa Verde Chapin Mesa unburned loessic soils (9/23/2008) } \\
\hline CMUB1 & 2282 & $13 S$ & 189217 & 4125602 & 0.056 \\
\hline CMUB2 & 2282 & $13 S$ & 189197 & 4125587 & 0.067 \\
\hline CMUB3 & 2313 & $13 S$ & 189014 & 4126366 & 0.085 \\
\hline CMUB4 & 2346 & $13 S$ & 189173 & 4127131 & 0.078 \\
\hline CMUB5 & 2352 & $13 S$ & 188952 & 4127145 & 0.062 \\
\hline CMUB6 & 2366 & $13 S$ & 189161 & 4127603 & 0.081 \\
\hline CMUB7 & 2379 & $13 S$ & 189194 & 4127782 & 0.101 \\
\hline CMUB8 & 2085 & $13 S$ & 192036 & 4118724 & 0.083 \\
\hline
\end{tabular}




$\begin{array}{llllll}\text { CMUB9 } & 2089 & 13 S & 191899 & 4118997 & 0.247 \\ \text { CMUB10 } & 2112 & 13 S & 191725 & 4119893 & 0.049 \\ \text { CMUB11 } & 2125 & 13 S & 191697 & 4120465 & 0.051 \\ \text { CMUB12 } & 2151 & 13 S & 190669 & 4121688 & 0.081\end{array}$

Mesa Verde Wetherill Mesa burned loessic soils (9/22/2008)

$\begin{array}{llllll}\text { WM34-1 } & 2273 & 13 S & 185321 & 4124962 & 0.038 \\ \text { WM34-2 } & 2274 & 13 S & 185306 & 4124962 & 0.073 \\ \text { WM34-3 } & 2274 & 13 S & 185300 & 4124996 & 0.032 \\ \text { WM34-4 } & 2277 & 13 S & 185327 & 4125021 & 0.031 \\ \text { WM34-5 } & 2276 & 13 S & 185314 & 4125008 & 0.030 \\ & & & & & \\ \text { WMB1 } & 2150 & 13 S & 186757 & 4120758 & 0.044 \\ \text { WMB2 } & 2150 & 13 S & 186768 & 4120717 & 0.046 \\ \text { WMB3 } & 2150 & 13 S & 186795 & 4120675 & 0.042 \\ \text { WMB4 } & 2149 & 13 S & 186794 & 4120632 & 0.062 \\ \text { WMB5 } & 2149 & 13 S & 186798 & 4120593 & 0.080\end{array}$

Mesa Verde Wetherill Mesa unburned loessic soils (9/22/2008)

$\begin{array}{llllll}\text { WMOG1 } & 2144 & 13 S & 186960 & 4120757 & 0.054 \\ \text { WMOG2 } & 2146 & 13 S & 186942 & 4120752 & 0.054 \\ \text { WMOG3 } & 2147 & 13 S & 186921 & 4120763 & 0.054 \\ \text { WMOG4 } & 2148 & 13 S & 186903 & 4120741 & 0.036 \\ \text { WMOG5 } & 2149 & 13 S & 186873 & 4120759 & 0.038 \\ & & & & & \\ \text { WMOG6 } & 2149 & 13 S & 186859 & 4120510 & 0.046 \\ \text { WMOG7 } & 2149 & 13 S & 186835 & 4120493 & 0.051 \\ \text { WMOG8 } & 2148 & 13 S & 186885 & 4120491 & 0.037 \\ \text { WMOG9 } & 2146 & 13 S & 186916 & 4120474 & 0.054 \\ \text { WMOG10 } & 2145 & 13 S & 186943 & 4120479 & 0.050\end{array}$

Mesa Verde Morefield Valley alluvial soils (9/23/2008)

$\begin{array}{llllll}\text { MV1 } & 2192 & 13 S & 197478 & 4126552 & 0.098 \\ \text { MV2 } & 2194 & 13 S & 197539 & 4126641 & 0.105 \\ \text { MV3 } & 2194 & 13 S & 197632 & 4126748 & 0.135 \\ \text { MV4 } & 2194 & 13 S & 197811 & 4126982 & 0.091 \\ & & & & & \\ \text { MV5 } & 2202 & 13 S & 197859 & 4127175 & 0.116 \\ \text { MV6 } & 2201 & 13 S & 197791 & 4127307 & 0.107 \\ \text { MV7 } & 2206 & 13 S & 197773 & 4127518 & 0.136 \\ \text { MV8 } & 2212 & 13 S & 197731 & 4127802 & 0.276 \\ \text { MV9 } & 2235 & 13 S & 197631 & 4128553 & 0.203\end{array}$

Mesa Verde Chapin Mesa side-valley terrace alluvial soils (9/23/2008)

$\begin{array}{llllll}\text { CMT1 } & 2140 & 13 S & 190936 & 4122347 & 0.055 \\ \text { CMT2 } & 2140 & 13 S & 190935 & 4122345 & 0.054 \\ \text { CMT3 } & 2143 & 13 S & 190929 & 4122338 & 0.068\end{array}$




\begin{tabular}{|c|c|c|c|c|c|}
\hline CMT4 & 2144 & $13 S$ & 190926 & 4122334 & 0.081 \\
\hline CMT5 & 2145 & $13 S$ & 190918 & 4122330 & 0.072 \\
\hline \multicolumn{6}{|c|}{ Bandelier transect soils (7/14/2009) } \\
\hline BA-1 & 2323 & $13 S$ & 377088 & 3966322 & 0.029 \\
\hline BA-2 & 2309 & $13 S$ & 378140 & 3966258 & 0.048 \\
\hline BA-3 & 2261 & $13 S$ & 379072 & 3966234 & 0.026 \\
\hline BA-4 & 2251 & $13 S$ & 379746 & 3965649 & 0.061 \\
\hline BA-5 & 2218 & $13 S$ & 380746 & 3965561 & 0.048 \\
\hline BA-6 & 2196 & $13 S$ & 381400 & 3964955 & 0.072 \\
\hline BA-7 & 2166 & $13 S$ & 382116 & 3964216 & 0.068 \\
\hline BA-8 & 2140 & $13 \mathrm{~S}$ & 382630 & 3963549 & 0.058 \\
\hline BA-9 & 2106 & $13 S$ & 383396 & 3962853 & 0.055 \\
\hline BA-10 & 2034 & $13 S$ & 384596 & 3962148 & 0.036 \\
\hline BA-11 & 2029 & $13 S$ & 384712 & 3961711 & 0.060 \\
\hline BA-12 & 2019 & $13 S$ & 385019 & 3961264 & 0.062 \\
\hline BA-13 & 2011 & $13 S$ & 385072 & 3961283 & 0.061 \\
\hline BA-14 & 1997 & $13 S$ & 385436 & 3960505 & 0.034 \\
\hline BA-15 & 1860 & $13 S$ & 384913 & 3960443 & 0.032 \\
\hline BA-16 & 1860 & $13 S$ & 384744 & 3960624 & 0.058 \\
\hline \multicolumn{6}{|c|}{ Janice Day Corn Field at Hopi $(9 / 28 / 2011)$} \\
\hline JD-1 & 1670 & $12 S$ & 543356 & 3954409 & 0.013 \\
\hline $\mathrm{JD}-2$ & 1670 & $12 S$ & 543334 & 3954453 & 0.007 \\
\hline JD-3 & 1670 & $12 S$ & 543319 & 3954430 & 0.005 \\
\hline JD-4 & 1670 & $12 S$ & 543358 & 3954363 & 0.032 \\
\hline JD-5 & 1670 & $12 S$ & 543374 & 3954378 & 0.040 \\
\hline \multicolumn{6}{|c|}{ Zuni fields (8/19-20/2008) } \\
\hline BA1A & 2080 & $13 S$ & 169941 & 3897512 & 0.053 \\
\hline BA1B & 2077 & $13 S$ & 169597 & 3897352 & 0.072 \\
\hline BC1A & 2089 & $13 S$ & 167660 & 3896512 & 0.105 \\
\hline BC1B & 2085 & $13 S$ & 167799 & 3896480 & 0.058 \\
\hline BC5A & 2030 & $13 S$ & 163569 & 3899993 & 0.082 \\
\hline BC5B & 2030 & $13 S$ & 163536 & 3899945 & 0.060 \\
\hline BU1 & 2097 & $13 S$ & 167944 & 3897509 & 0.081 \\
\hline WE1 & 2086 & $13 S$ & 168335 & 3897416 & 0.048 \\
\hline BU3A & 2091 & $13 S$ & 167717 & 3896426 & 0.053 \\
\hline BU3B & 2092 & $13 S$ & 167700 & 3896434 & 0.079 \\
\hline NA2A & 2066 & $13 S$ & 172802 & 3907289 & 0.082 \\
\hline NA2B & 2064 & $13 S$ & 172883 & 3907293 & 0.073 \\
\hline NA3A & 2072 & $13 S$ & 170807 & 3906877 & 0.074 \\
\hline NA3B & 2070 & $13 S$ & 170794 & 3906683 & 0.123 \\
\hline NC1A & 2081 & $13 S$ & 175495 & 3908770 & 0.093 \\
\hline NC1B & 2084 & $13 S$ & 175393 & 3908685 & 0.057 \\
\hline $\mathrm{NC} 2 \mathrm{~A}$ & 2074 & $13 S$ & 175182 & 3906713 & 0.069 \\
\hline NC2B & 2074 & $13 \mathrm{~S}$ & 175525 & 3906800 & 0.054 \\
\hline
\end{tabular}




\begin{tabular}{|c|c|c|c|c|c|}
\hline NC3A & 2076 & $13 \mathrm{~S}$ & 175101 & 3908723 & 0.122 \\
\hline NC3B & 2075 & $13 \mathrm{~S}$ & 175065 & 3908757 & 0.120 \\
\hline PA1A & 2050 & $13 \mathrm{~S}$ & 172034 & 3892391 & 0.089 \\
\hline PA1B & 2051 & $13 \mathrm{~S}$ & 172147 & 3892493 & 0.082 \\
\hline PA2A & 2061 & $13 \mathrm{~S}$ & 171871 & 3891061 & 0.056 \\
\hline PA2B & 2058 & $13 \mathrm{~S}$ & 171881 & 3891215 & 0.025 \\
\hline PC1A & 2072 & $13 \mathrm{~S}$ & 172229 & 3890478 & 0.063 \\
\hline PC1B & 2067 & $13 \mathrm{~S}$ & 172196 & 3890622 & 0.093 \\
\hline PC2A & 2060 & $13 \mathrm{~S}$ & 171100 & 3891505 & 0.061 \\
\hline PC2B & 2055 & $13 S$ & 171195 & 3891732 & 0.072 \\
\hline PC3A & 2044 & $13 \mathrm{~S}$ & 170965 & 3893125 & 0.119 \\
\hline РC3B & 2044 & $13 \mathrm{~S}$ & 171092 & 3893236 & 0.105 \\
\hline \multicolumn{6}{|c|}{ Chaco Corridor } \\
\hline \multicolumn{6}{|c|}{ Chaco Canyon } \\
\hline SG08-1 & 1881 & $13 \mathrm{~S}$ & 232270 & 3993416 & 0.062 \\
\hline SG08-2 & 1870 & $13 S$ & 232419 & 3993708 & 0.135 \\
\hline SG08-3 & 1870 & $13 \mathrm{~S}$ & 232633 & 3994201 & 0.111 \\
\hline WR08-1 & 1882 & $13 S$ & 235012 & 3993138 & 0.022 \\
\hline WR08-2 & 1881 & $13 \mathrm{~S}$ & 235120 & 3993228 & 0.026 \\
\hline PB08-1 & 1851 & $13 S$ & 231081 & 3996239 & 0.028 \\
\hline PB08-2 & 1860 & $13 \mathrm{~S}$ & 231191 & 3996043 & 0.054 \\
\hline CC08-1 & 1866 & $13 \mathrm{~S}$ & 231454 & 3995909 & 0.044 \\
\hline KN08-1 & 1891 & $13 S$ & 237241 & 3992489 & 0.029 \\
\hline MB08-1 & 1888 & $13 \mathrm{~S}$ & 236558 & 3993668 & 0.056 \\
\hline MB08-2 & 1881 & $13 S$ & 236428 & 3993593 & 0.075 \\
\hline MB08-3 & 1879 & $13 \mathrm{~S}$ & 236228 & 3993440 & 0.027 \\
\hline LH08-1 & 1876 & $13 S$ & 234490 & 3994323 & 0.043 \\
\hline GW08-1 & 1914 & $13 S$ & 242421 & 3993387 & 0.073 \\
\hline GW08-2 & 1909 & $13 S$ & 241943 & 3993347 & 0.084 \\
\hline GW08-3 & 1906 & $13 S$ & 240729 & 3992502 & 0.096 \\
\hline FB08-1 & 1887 & $13 S$ & 237470 & 3990851 & 0.016 \\
\hline FB08-2 & 1886 & $13 S$ & 237235 & 3990990 & 0.047 \\
\hline \multicolumn{6}{|l|}{ Rio Chaco } \\
\hline KK08-1 & 1851 & $13 S$ & 222941 & 3991737 & 0.035 \\
\hline KK08-2 & 1846 & $13 S$ & 223294 & 3991988 & 0.044 \\
\hline KK08-3 & 1843 & $13 S$ & 223627 & 3991998 & 0.049 \\
\hline KK08-4 & 1841 & $13 S$ & 223660 & 3992230 & 0.047 \\
\hline KK08-5 & 1840 & $13 \mathrm{~S}$ & 223653 & 3992466 & 0.037 \\
\hline CDR08-1 & 1821 & $13 S$ & 222813 & 3997921 & 0.008 \\
\hline CDR08-2 & 1822 & $13 S$ & 223064 & 3998237 & 0.005 \\
\hline CDR08-3 & 1822 & $13 S$ & 223155 & 3998557 & 0.029 \\
\hline CDR08-4 & 1820 & $13 S$ & 222857 & 3998204 & 0.006 \\
\hline GB08-1 & 1687 & $13 S$ & 185266 & 4008780 & 0.064 \\
\hline GB08-2 & 1688 & $13 S$ & 185755 & 4008256 & 0.085 \\
\hline GB08-3 & 1691 & $13 S$ & 186624 & 4007758 & 0.057 \\
\hline GB08-4 & 1697 & $13 S$ & 187908 & 4007552 & 0.075 \\
\hline
\end{tabular}




\begin{tabular}{|c|c|c|c|c|c|}
\hline GB08-5 & 1706 & $13 S$ & 189163 & 4007618 & 0.074 \\
\hline IC08-1 & 1745 & $13 S$ & 197787 & 4001989 & 0.021 \\
\hline WC08-1 & 1710 & $13 S$ & 190263 & 4007951 & 0.070 \\
\hline WC08-2 & 1722 & $13 S$ & 191328 & 4007140 & 0.059 \\
\hline WC08-3 & 1736 & $13 S$ & 192110 & 4006315 & 0.070 \\
\hline EC08-1 & 1961 & $13 S$ & 251859 & 3984943 & 0.042 \\
\hline EC08-2 & 1950 & $13 S$ & 251960 & 3985359 & 0.028 \\
\hline EC08-3 & 1942 & $13 S$ & 252123 & 3985958 & 0.027 \\
\hline PP08-1 & 1970 & $13 S$ & 260213 & 3986632 & 0.060 \\
\hline PP08-2 & 1976 & $13 S$ & 260419 & 3986254 & 0.035 \\
\hline PP08-3 & 1970 & $13 S$ & 261195 & 3985638 & 0.067 \\
\hline PP08-4 & 1974 & $13 S$ & 260819 & 3985218 & 0.080 \\
\hline PP08-5 & 1981 & $13 S$ & 259731 & 3983069 & 0.070 \\
\hline \multicolumn{6}{|l|}{ Chuska Slope } \\
\hline SS08-1 & 1750 & $13 S$ & 162718 & 4016234 & 0.028 \\
\hline SS08-2 & 1740 & $13 S$ & 163406 & 4016321 & 0.055 \\
\hline TGHBM08-1 & 1855 & $13 S$ & 155749 & 4015408 & 0.022 \\
\hline TGHBM08-2 & 1840 & $13 S$ & 156275 & 4015921 & 0.022 \\
\hline TGHBM08-3 & 1871 & $13 S$ & 155047 & 4015315 & 0.047 \\
\hline $\mathrm{CH} 08-1$ & 1776 & $13 S$ & 159663 & 4014143 & 0.028 \\
\hline $\mathrm{CH} 08-2$ & 1761 & $13 S$ & 160379 & 4014124 & 0.043 \\
\hline $\mathrm{CH} 08-3$ & 1756 & $13 S$ & 161078 & 4014844 & 0.034 \\
\hline CTW08-1 & 1697 & $13 S$ & 166611 & 4022354 & 0.030 \\
\hline CTW08-2 & 1714 & $13 S$ & 164198 & 4022355 & 0.039 \\
\hline CTW08-3 & 1693 & $13 S$ & 167329 & 4023043 & 0.088 \\
\hline CTW08-4 & 1691 & $13 S$ & 167676 & 4023074 & 0.043 \\
\hline CTW08-5 & 1630 & $13 S$ & 178972 & 4029615 & 0.038 \\
\hline CTW08-6 & 1623 & $13 S$ & 178469 & 4029138 & 0.082 \\
\hline
\end{tabular}


Suplementary Table 4. Elevation, mean summer T, annual T, GDD, and FFD for Southwest Colorado weather stations

\begin{tabular}{|c|c|c|c|c|c|c|c|c|c|c|}
\hline & Ele $(m)$ & Avg JJAS T $\left({ }^{\circ} \mathrm{C}\right)$ & $1 \sigma$ & Avg Ann T & $1 \sigma$ & Avg GDD & $1 \sigma$ & FFD 90\%P & 120 FFD P & $>115$ FFD (\%) \\
\hline Hovenweep & 1597 & 21.8 & 0.9 & 10.5 & 0.53 & 1756 & 146 & 125 & $>90$ & 94 \\
\hline Cortez & 1888 & 19.6 & 0.8 & 9.07 & 0.49 & 1366 & 140 & 110 & 59 & 73 \\
\hline Ignacio & 1960 & 17.6 & 0.9 & 7.52 & 0.88 & 1040 & 131 & 80 & 18 & 22 \\
\hline Durango & 2030 & 17.4 & 0.8 & 8.33 & 0.47 & 1011 & 112 & 88 & 32 & 36 \\
\hline Yellow Jacket & 2091 & 19.0 & 1.0 & 8.49 & 0.78 & 1285 & 167 & 116 & 78 & 88 \\
\hline Mesa Verde & 2159 & 19.8 & 1.0 & 9.52 & 0.68 & 1421 & 181 & 122 & $>90$ & 92 \\
\hline Vallecito & 2332 & 15.5 & 1.0 & 5.78 & 0.75 & 738 & 126 & 85 & 18 & 21 \\
\hline Rico & 2687 & 12.2 & 0.7 & 3.67 & 0.64 & 336 & 67 & 28 & 0 & 0 \\
\hline
\end{tabular}

FFD $90 \% \mathrm{P}$ indicates $90 \%$ probability of those number of FFD between $0^{\circ} \mathrm{C}$ in spring and $0^{\circ} \mathrm{Cn}$ in autumn 120 FFD P indicates the probability (\%) of achieving 120 FFD

$>115$ FFD (\%) indicates the percent of the time that the site has achieved greater than 115 FFD 